\title{
REVIEW
}

\section{Thyroid function disruptors: from nature to chemicals}

\author{
Karen Jesus Oliveira1, Maria Isabel Chiamolera², Gisele Giannocco ${ }^{2,3}$, Carmen Cabanelas Pazos-Moura4 and \\ Tania Maria Ortiga-Carvalho5
}

1Departamento de Fisiologia e Farmacologia, Laboratório de Fisiologia Endócrina e Metabologia, Universidade Federal Fluminense, Rio de Janeiro, Brazil 2Disciplina de Endocrinologia e Metabologia, Laboratório de Endocrinologia Molecular e Translacional, Escola Paulista de Medicina, Universidade Federal de São Paulo, São Paulo, Brazil

32Departamento de Ciências Biológicas, Universidade Federal de São Paulo, Diadema, Brazil

4Laboratorio de Endocrinologia Molecular, Instituto de Biofisica Carlos Chagas Filho, Universidade Federal do Rio de Janeiro, Rio de Janeiro, Rio de Janeiro, Brazil

5Laboratório de Endocrinologia Translacional, Instituto de Biofisica Carlos Chagas Filho, Universidade Federal do Rio de Janeiro, Rio de Janeiro, Rio de Janeiro, Brazil

Correspondence should be addressed to T M Ortiga-Carvalho: taniaort@biof.ufrj.br

\begin{abstract}
The modern concept of thyroid disruptors includes synthetic chemicals and bioactive compounds from food that interfere with any aspect of the hypothalamus-pituitarythyroid axis, thyroid hormone biosynthesis and secretion, blood and transmembrane transport, metabolism and local actions of thyroid hormones. This review highlights relevant disruptors that affect populations through their diet: directly from food itself (fish oil and polyunsaturated fatty acids, pepper, coffee, cinnamon and resveratrol/ grapes), through vegetable cultivation (pesticides) and from containers for food storage and cooking (bisphenol A, phthalates and polybrominated diphenyl ethers). Due to the vital role of thyroid hormones during every stage of life, we review effects from the gestational period to adulthood, including evidence from in vitro studies, rodent models, human trials and epidemiological studies.
\end{abstract}
Key Words
- bioactive food compounds
- chemical disruptors
$\rightarrow \mathrm{TSH}$
- thyroid hormones

Journal of Molecular Endocrinology (2019) 62, R1-R19

\section{Introduction: temporal description, definitions, basic concepts}

Although the terms endocrine disruption and endocrine disruptors were coined at the Wingspread Conference in 1991, the concept of endocrine alterations caused by synthetic chemicals has followed the larger context of the environmental movement that has had various influences on science since the 1960s and 1970s (Schug et al. 2016). Several factors have guided this journey, such as Rachel Carson's 1962 book Silent Spring; several wildlife studies showing reproductive alterations in birds, alligators and fish (Gilbertson \& Reynolds 1972, Aulerich et al. 1973, Aulerich \& Ringer 1977, Semenza et al. 1997, Jobling et al.
2002); and the disastrous use of an estrogen analog, diethylstilbestrol, which was used by millions of women during pregnancy to reduce the risk of miscarriage: later this use was linked to the occurrence of unusual cancers and reproductive system malformations for those exposed in utero (McLachlan et al. 1980, Newbold et al. 1985). Dietary phytoestrogens, which are phytochemicals that are structurally similar to estrogens, are able to bind and activate estrogen receptors (ERs), mimicking or interfering with endogenous estrogen pathways. Therefore, these plant-derived compounds can induce many health 
benefits but can also cause harmful effects, such as an elevated breast cancer risk and premature puberty (Sauve \& Desrosiers 2014).

In 2012, the Endocrine Society published (Zoeller et al. 2012, Schug et al. 2016) a statement of principles and used the following definition to describe endocrinedisrupting chemicals (EDCs): chemicals, or mixtures of chemicals, which interfere with any aspect of hormone action (Patisaul \& Jefferson 2010, Bode \& Dong 2015). There are a great variety of agents that have been reported to have endocrine-related effects, including more than 1000 chemicals from several chemical classes (DiamantiKandarakis et al. 2009). These chemicals are not identified by their chemical structure or by a specific type of usage but rather by their mechanisms of action and ability to alter endocrine system function. In this context, there are a large number of chemicals with different structures present in food, and many of them have biological properties, including endocrine-disrupting-related effects (Gore et al. 2015), which extends the concept of endocrine disrupters beyond man-made chemicals. Several reviews have explored the effects of chemicals and bioactive compounds in food on the reproductive system. In addition to effects on the reproductive system, endocrine disruptors also affect different endocrine glands, including the thyroid, a fundamental gland for neural development. Thyroid hormones (THs) are released under the regulation of the hypothalamus-pituitary-thyroid (HPT, Fig. 1) axis and other factors that control the mechanism of action of THs (Fig. 2), which have been extensively reviewed elsewhere (Ortiga-Carvalho et al. 2014, 2016, Bernal et al. 2015). Importantly, endocrine disruptors may act at any level of this regulation. In this review, we explore the effects of natural and artificial compounds on thyroid function and regulation.

\section{Bioactive food compounds as thyroid-disrupting factors}

Some vegetables, such as cabbage, broccoli and cassava, are a source of antithyroid compounds, such as thiocyanate and thioamides, which are well-characterized goitrogens (Gaitan 1990, Felker et al. 2016, Willemin \& Lumen 2017). However, the consumption of other foods and food-related compounds, such as soy protein and soybean isoflavones, as well as other flavonoids, may interfere with thyroid function. These effects of those compounds have been reviewed recently by several authors (Doerge \& Chang 2002, Messina \& Redmond 2006, Xiao 2008, de Souza Dos Santos et al. 2011). Here, we focus on reviewing the thyroid-disrupting properties of other less well-known bioactive food compounds.

\section{Fish oil and polyunsaturated fatty acids}

Essential fatty acids play important roles in plasma membrane integrity and function, energy production and as precursors of bioactive lipids at all stages of life. The long chain $n-3$ polyunsaturated fatty acid $(n-3$ PUFA) docosahexaenoic acid (22:6n-3; DHA) is especially important to brain development during gestation and infancy (Chilton et al. 2017). Male rat pups supplemented with DHA during the first 6 weeks of life exhibited higher serum thyroid-stimulating hormone (TSH) levels without changes in other pituitary hormones (Clandinin et al. 1998), which suggests that DHA interferes in the HPT axis (Fig. 1). However, other authors (Souza et al. 2010) studying rats supplemented with fish oil, which is enriched in $n-3$ PUFAs, from lactation until 11 weeks of age found no alterations in serum TSH or TH concentrations. The authors detected higher levels of the TH receptor $\beta$ (THR $\beta$ ) protein in the liver, accompanied by increased mitochondrial glycerophosphate dehydrogenase (mGPD) activity; mGPD is a THR $\beta$-mediated triiodothyronine (T3) target, suggesting that fish oil increases $\mathrm{TH}$ sensitivity in this tissue. However, deiodinase type 1 (D1, DIO1) activity, another recognized marker of $\mathrm{TH}$ action in the liver (Fig. 2), was not changed, suggesting that the $n-3$ PUFAs present in fish oil might interfere with T3 action in a target-specific manner (Souza et al. 2011). Another study showed that hepatocytes treated with T3 and eicosapentaenoic acid (20:5n-3; EPA) showed a reduction of 70\% in the effect of $\mathrm{T} 3$ on thyroid hormone responsive spot 14 (Thsrp) gene transcription (Jump et al. 1993). However, the authors showed that the Thsrp TH-response element (TRE) was not directly sensitive to EPA inhibition. The PUFA-responsive element was found to be located in a region that potentiates T3-mediated activation of Thsrp gene transcription.

In hypothyroid patients, higher levels of free fatty acids were associated with lower symptom severity, along with lower serum TSH and higher thyroxine (T4) and T3 levels, than in patients with low levels of plasma free fatty acids (Makino et al. 2001). These authors also showed, in methimazole-induced hypothyroid rats, that chronic EPA supplementation for 28 days reduced the methimazole-induced drop in $\mathrm{TH}$ levels and the consequent increase in serum TSH levels (Makino et al. 2001). This study suggests that EPA exerts a direct stimulatory effect on the thyroid. 
Chemicals

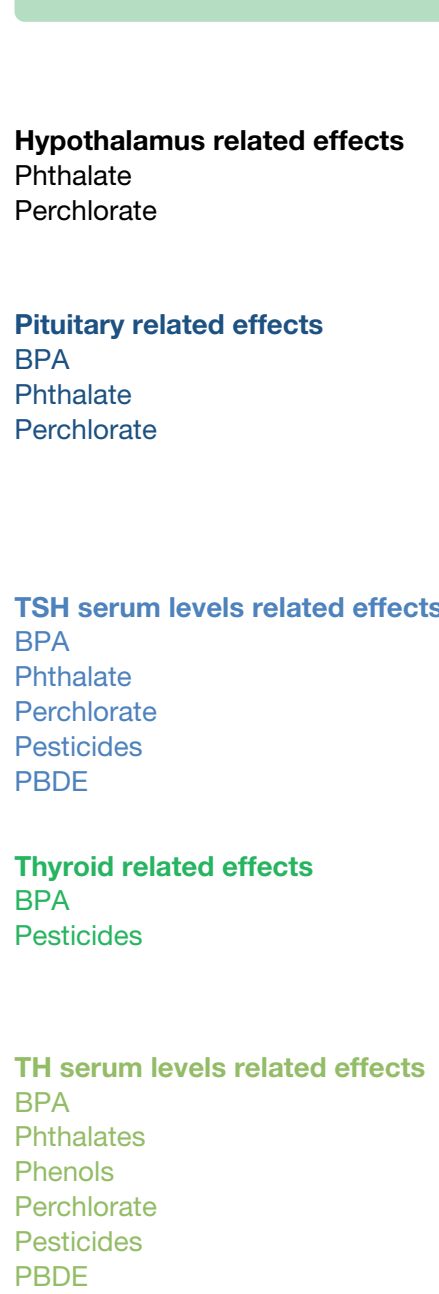

Bioactive food compounds

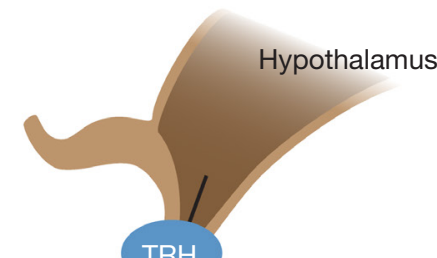

2

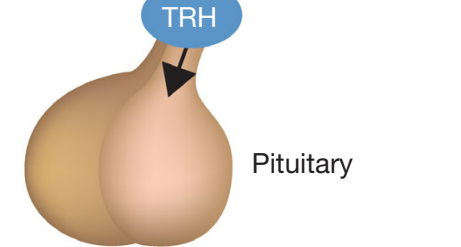

3
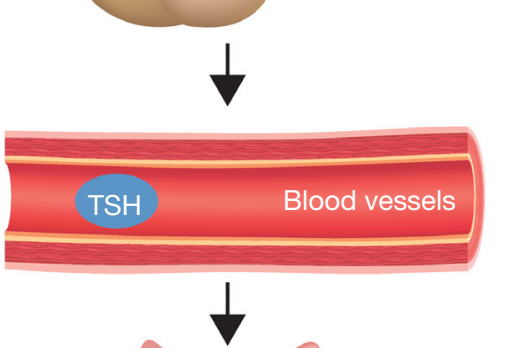

Pituitary related effects

Caffeine

TSH serum levels related effects Polyunsaturated fatty acid (DHA) Polyunsaturated fatty acid (EPA) Caffeine

Resveratrol

Thyroid related effects Resveratrol

\section{Figure 1}

Simple scheme of the hypothalamus-pituitary-thyroid axis. The hypothalamus produces thyrotropin-releasing hormone (TRH), which stimulates the pituitary to release thyrotropin (thyroid-stimulating hormone, TSH). TSH is released in circulation and stimulates the thyroid gland to produce thyroid hormones (THs) (Ortiga-Carvalho et al. 2014). The thyroid produces the main THs, thyroxine (T4) and triiodothyronine (T3). TSH stimulates all the steps of $\mathrm{TH}$ biosynthesis and release, as well as the expression and activity of several proteins: the solute carrier family $5 \mathrm{~A}$ (also known as sodium-iodide symporter (NIS)), pendrin (PDS), dual oxidase type 2 (DUOX), thyroid peroxidase (TPO), thyroglobulin (Agic et al. 2007) and deiodinases type 1 (D1, DIO1), 2 (D2, DIO2) and 3 (D3, DIO3). In physiologic balance, T4 and T3 (3) regulate their own concentrations in the blood by negative feedback acting at the hypothalamic (1) and pituitary (2) levels (Ortiga-Carvalho et al. 2016). BPA, bisphenol A; DHA, docosahexaenoic acid; EPA, eicosapentaenoic acid; PBDE, polybrominated diphenyl ether.

\section{Pepper and piperine}

Piperine is the main alkaloid found in the fruit Piper nigrum, which is also known as black pepper. Studies have shown that piperine enhances the bioavailability of several drugs and nutraceuticals and possesses important pharmacological effects, including anticancer, antiinflammatory and antimicrobial activities (Chavarria et al. 2016). Although there is no evidence for the effects of piperine in humans, studies conducted in rodents point to a thyroid-disrupting effect of pepper and isolated piperine. Two different preparations of the Piper fruit were tested in mice. A water extract induced a reduction in serum T3 and T4 levels after 15 days of treatment. An ethanolic extract had the opposite effect and induced an elevation in TH levels (Panda \& Kar 2003b). The study did not evaluate the chemical composition of the extracts to identify the bioactive component responsible for the different effects observed. Another study investigated the effect of isolated piperine administered orally for 15 days to mice. This study found suppressed hepatic D1 activity in the groups receiving high or low doses of piperine, with 


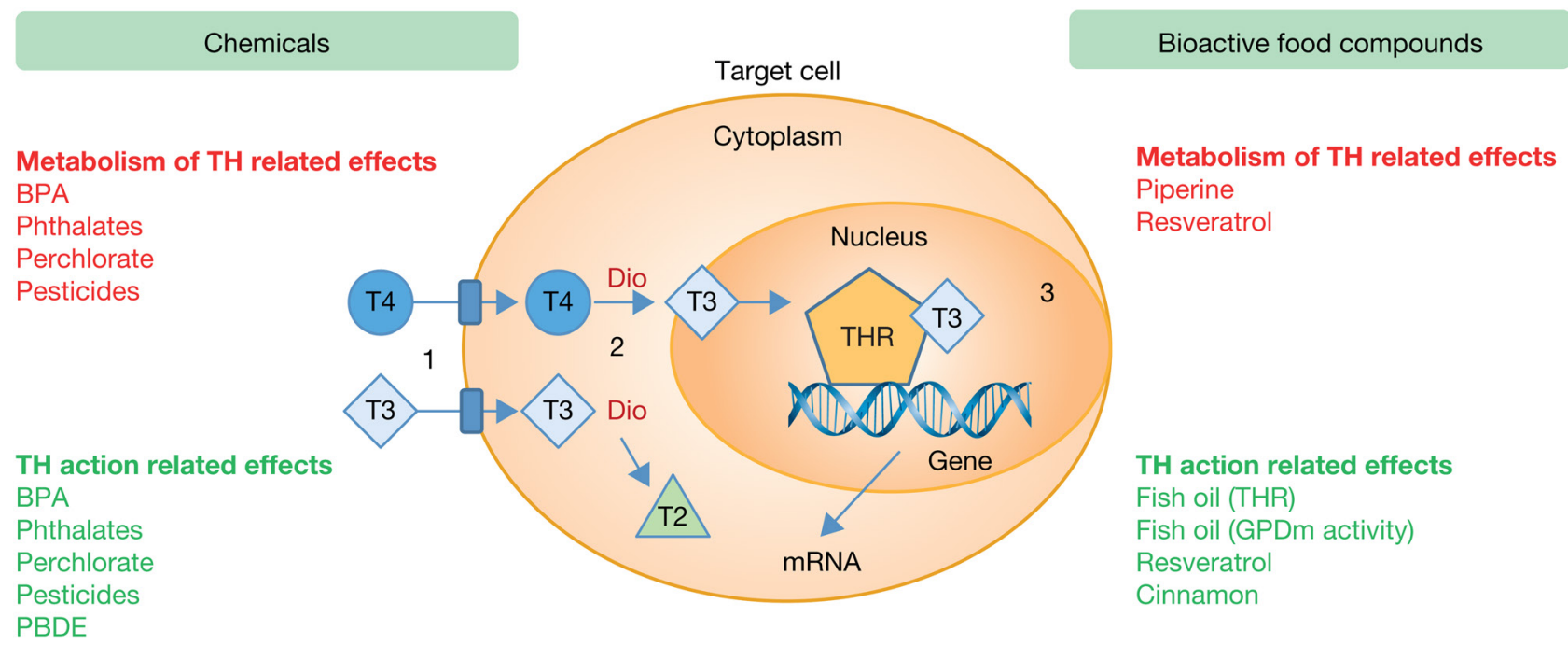

Figure 2

Schematic local action of thyroid hormones (THs). (1) Thyroxine (T4) and triiodothyronine (T3) reach the cytoplasm by transport through the plasma membrane. There are several proteins able to transport T4 and T3; however, monocarboxylate transporter 8 (MCT-8, S/c16a2) is the most specific (Bernal et al. 2015). (2) T4 and T3 are activated or inactivated by deiodinases type 1 (D1, DIO1), 2 (D2, DIO2) and 3 (D3, DIO3) (Ortiga-Carvalho et al. 2016). (3) T3 is the TH able to bind TH receptors (THRs) that are encoded by two different genes (Thra and Thrb), which encode 3 main isoforms of these receptors: THR $\alpha 1$ and THR $\beta 1$ and THR $\beta 2$. THRs bind to DNA at the TRE, modulating specific gene expression patterns (Ortiga-Carvalho et al. 2014). BPA, bisphenol A; DHA, docosahexaenoic acid; EPA, eicosapentaenoic acid; GPDm, mitochondrial glycerophosphate dehydrogenase; PBDEs, polybrominated diphenyl ethers; T2, 3,5-diio-L-thyronine; THR, thyroid hormone receptor.

the former showing reduced serum T3 and T4 levels and the latter only showing reduced serum T3 levels (Panda $\&$ Kar 2003a). These authors suggested that piperine has a direct suppressive effect on the thyroid at higher doses, but at lower doses, it directly inhibits the peripheral metabolism of THs mediated by the D1 in the liver.

\section{Coffee and caffeine}

Coffee contains over a thousand components, including many with biological activity, such as caffeine, diterpene alcohols and chlorogenic acid, which are potential nutraceuticals. Although the biological effects of coffee are not restricted to caffeine, this is the most studied component of coffee (O'Keefe et al. 2013). The effects of caffeine on thyroid function in animal models are inconclusive due to variations in the species, ages and doses studied. Caffeine has been used for more than 40 years as a prescribed drug in neonatal medicine, mostly for apnea treatment, but the overall effect of caffeine exposure at this age is poorly understood (Kreutzer \& Bassler 2014). In newborn rats, a single administration of caffeine induced a biphasic response, with plasma T4 levels elevated after $4 \mathrm{~h}$ and then reduced $24 \mathrm{~h}$ after administration (Clozel et al. 1983). These authors suggested that the decrease in $\mathrm{T} 4$ concentration was a direct effect of caffeine on the thyroid gland since no significant change in thyrotropin-releasing hormone (TRH)-stimulated TSH levels were observed at the same point. However, after 10 days of caffeine administration, basal serum TSH and T4 concentrations were increased, but after TRH stimulation, TSH levels were attenuated by caffeine, suggesting that chronic exposure to caffeine may lead to exhaustion of the pituitary reserve (Clozel et al. 1983). A study performed in preterm infants showed that caffeine was negatively associated with TSH levels at the 7th postnatal day (PND) but was positively associated with TSH levels at the 14th day, and caffeine showed no correlation at the 28th day. The reverse T3 (rT3) level was negatively correlated with caffeine exposure at the 7th PND. Therefore, these authors suggested a mild and transitory effect of caffeine on thyroid function in newborn humans (Williams et al. 2005). In adult rats, an acute injection of caffeine induced a decrease in TSH levels after 1-6h, followed by a reduction in $\mathrm{T} 3$ and $\mathrm{T} 4$ levels after $4 \mathrm{~h}$. An injection of anti-somatostatin antiserum blocked the inhibitory effect of caffeine on TSH secretion, and the incubation of an isolated pituitary gland with caffeine did not elicit changes in TSH release, suggesting that the effect of caffeine on TSH release appears to be mediated by hypothalamus-derived somatostatin (Spindel et al. 1984). The chronic exposure to caffeine associated with regular intake induces tolerance related to hemodynamic and humoral effects (O'Keefe et al. 2013), and this seems to extend to the effects on thyroid function as well. 
Spindel et al. (1984) observed that an acute injection of caffeine induced an inhibitory effect on serum TSH; however, a 7-day treatment with caffeine induced tolerance to its effect on serum TSH. A possible toleranceinducing effect on thyroid function was also observed in Syrian golden hamsters treated for 90 days with caffeine. After 3 days of treatment, the authors observed a transient increase in serum T3 levels, without changes in T4 levels. After 90 days of treatment, no changes in serum T3 and T4 levels or in thyroid histopathology were identified (Bartsch et al. 1996). Evidence in humans is complex but also points to a transitory effect and a possible tolerancerelated outcome. The acute intake of caffeine did not promote any changes in serum TSH or T3 levels over $4 \mathrm{~h}$ in healthy adults who normally drank one to three cups of coffee a day (Spindel et al. 1984). In a study conducted by Friedrich et al. (2017), a strong positive correlation between the levels of free T4 (FT4) and urinary trigonelline, a urinary marker of coffee consumption in humans (Lang et al. 2011), was observed in cross-sectional analyses. However, this positive association was lost in longitudinal analyses, and higher trigonelline levels in urine samples were related to a greater decline in FT4.

\section{Grape and resveratrol}

Resveratrol is a natural polyphenol stilbene found in foods such as grapes, berries and peanuts, as well as in red wine, which is the main source of resveratrol in the Mediterranean diet (Gambini et al. 2015). In vitro resveratrol incubation of the rat thyroid cell line FRTL-5 induced a rapid and transient stimulatory effect of iodide trapping, with the highest effect occurring between $6 \mathrm{~h}$ and $12 \mathrm{~h}$, and after $24 \mathrm{~h}$, no changes were observed. The stimulatory effect was dose dependent and associated with increased levels of the solute carrier family 5A (also known as sodium-iodide symporter or NIS) protein. In addition, the effect of resveratrol on iodide uptake after $6 \mathrm{~h}$ of incubation was additive to the effect TSH stimulation and was mediated by a cAMPindependent pathway (Sebai et al. 2010). Interestingly, after $48 \mathrm{~h}$ of incubation, the effect of resveratrol on FRTL-5 cells was the opposite: it induced a reduction in iodide uptake accompanied by the reduced expression of NIS and the gene that encodes this transporter, Slc5a5 (Giuliani et al. 2014). At this time point, resveratrol also downregulated the expression of TSH receptor (Tshr), thyroid peroxidase (Tpo), thyroglobulin (Agic et al. 2007) and the related transcriptional factors NK2 homeobox 1
(Nkx2-1), forkhead box E1 (Foxe1) and paired box 8 (Pax8) mRNAs in FRTL-5 cells (Giuliani et al. 2017). In vivo, resveratrol administered to adult male rats for 14 days induced lower NIS protein expression levels and reduced radioiodine uptake by the thyroid, with no significant effects on thyroid growth or TSH and TH concentrations (Giuliani et al. 2014). In a chronic study, the treatment of adult male rats with resveratrol for 60 days promoted increased thyroid mass and higher serum TSH levels, without altering the serum concentration of THs, and the histological analyses showed an increased number of follicles, with lower thyroglobulin concentrations in the colloid (Giuliani et al. 2017). Therefore, these data suggest that resveratrol elicits a direct antithyroid effect and a mild goitrogenic effect when administered chronically. The thyroid-related effects of resveratrol can be different in females, as showed previously (Bottner et al. 2006). Ovariectomized female rats treated chronically with resveratrol for 3 months showed higher levels of serum T3, without changes in serum T4 or TSH levels, pituitary TSH beta subunit (Tshb) mRNA expression, thyroid weight or the gross morphology of the thyroid. In addition, resveratrol had no effect on TRH-stimulated TSH secretion from isolated pituitary cells (Bottner et al. 2006). These authors pointed out that the higher T3 levels observed in their study cannot be related to the estrogenic action of resveratrol since $17 \beta$-estradiol treatment of ovariectomized rats did not promote any change in the concentration of T3. In addition, the authors suggested that the higher T3 levels should be related to increased D1 activity or altered levels of T3-binding proteins such as thyroxine-binding protein (TBG) (Bottner et al. 2006). Resveratrol administration for 26 weeks to female rats fed a high-fat diet (HFD) attenuated the increase in total serum T4 levels and the reduction in total serum T3 levels induced by a HFD, while this treatment increased the levels of free T4 and T3 in HFD-fed mice. Resveratrol also increased levels of the Dio1 mRNA in the hearts of HFD-fed mice, restoring expression levels to those observed in rats fed a normolipid diet, and resveratrol decreased TR $\alpha 1$ (Thra) mRNA expression in the hearts of HFD-fed rats. These results indicate that resveratrol can affect the peripheral metabolism and actions of THs (Cheserek et al. 2016).

Human studies concerning the effects of grapes or resveratrol on thyroid function are scarce, and they do not point to a thyroid-disrupting effect; these studies have only explored a few parameters related to the thyroid physiology (Tome-Carneiro et al. 2012, 2013). 


\section{Cinnamon}

Cinnamon is a common spice that is used worldwide and has been widely studied as a nutraceutical for the management of insulin resistance, obesity and dyslipidemia (Rafehi et al. 2012, Medagama 2015). According to the results of human, animal or in vitro studies, cinnamon and its active biological compounds interfere with the biosynthesis or action of many hormones, such as insulin, glucagon-like peptide-1 (GLP1), ghrelin and leptin (Hlebowicz et al. 2009, Rafehi et al. 2012, Camacho et al. 2015, Lopes et al. 2015, Medagama 2015, Bento-Bernardes et al. 2017). In this context, a study showed that rats supplemented with a water extract of cinnamon exhibited lower serum T3 levels accompanied by unaltered serum T4 and TSH levels. Cinnamon did not seem to impact pituitary or liver $\mathrm{TH}$ signaling or metabolism since Thrb or Dio expression in these tissues was similar to that in controls. However, cinnamon-treated rats showed a strong reduction of Thra and THR $\alpha$ expression in the cardiac ventricle, with important consequences for the expression of calcium handling proteins (Gaique et al. 2016).

\section{Chemicals as thyroid-disrupting factors}

Due to the need to increase the productivity of agriculture and industry, thousands of different chemicals have been developed. Many of these artificial chemicals (such as hexachlorobenzene (HCB) and dichlorodiphenyltrichloroethane (DDT)) have been used as pesticides to improve agricultural efficiency. Plastic components and additives, such as bisphenol A (BPA), phthalates and benzo(a)pyrene diol epoxide (BPDE), are frequently used in products that people use daily to improve industrial processes. The present manuscript will concentrate on describing published data for pesticides that are directly involved in food contamination and chemicals that contaminate food due to their presence in plastic containers (BPA, phthalates and BPDEs) to present a more comprehensive review of selected chemicals. However, several other substances have already been shown to disrupt thyroid function, such as perchlorate, thiocyanate, nitrate, polychlorinated biphenyls, triclosan, dioxins and furans, styrenes, sunscreens and lead. Some of these substances can also reach humans and other animals through food contamination (Pearce \& Braverman 2009).

Pesticides are chemical agents that are known to act as endocrine disrupters. For example, in 2014, the European Food Safety Authority reported that of 287 pesticides tested, more than a third of them (103) had thyroiddisrupting properties (Sugiyama et al. 2005, Pearce \& Braverman 2009, Bellanger et al. 2015, Leung et al. 2016).

\section{Plasticizers}

Plastic items are produced and used intensely worldwide, generating several environmental concerns associated with not only individual plastic use but also related to contamination due to leakage of plastic components into the environment. Two important substances used in the plastics industry that are correlated with endocrine disruption, particularly HPT axis disruption, are BPA and phthalates (Talsness et al. 2009). Humans can ingest these components because they can leach from food cans, microwave containers and polycarbonate bottles.

BPA was shown to interfere with the binding of T3 to its receptor by acting as an antagonist, both in vitro (Moriyama et al. 2002, Gayathri et al. 2004) and in vivo (Zoeller et al. 2005), particularly to the beta isoform of THR (THR $\beta$ ), mainly disrupting the negative feedback of THs in the pituitary (Zoeller et al. 2005). It was also shown, in vitro, that BPA suppressed expression of the gene encoding RXR gamma, which forms heterodimers with THR (Iwamuro et al. 2006). Similarly, several phthalate metabolites that act as THR antagonists were detected in Chinese rivers (Ibhazehiebo \& Koibuchi 2011, Shi et al. 2011, Hu et al. 2013, Li et al. 2014), which was corroborated by a transient transfection study with low phthalate doses (Hansen et al. 2016).

The capacity of BPA to interfere with THR transcription activity has been analyzed by several studies, with some of them showing interference at the nuclear transcriptional level, particularly for T3-related genes (Xu et al. 2007, Heimeier et al. 2009, Hansen et al. 2016, Jiang et al. 2016), and one study demonstrated interference at a nongenomic level (Sheng et al. 2012). BPA and several BPA analogs that have recently been introduced in the plastics industry were tested on different TH-responsive cell lines (GH3, FRTL-5 and rat cerebellar cells), and the results showed that they interfered with the expression of genes involved in TH synthesis (Slc5, Tg and Tpo), thyroid cell activity/ proliferation (Tshr, Tshb, Thrb, Thra, Dio1 and Dio2) and thyroid transcriptional regulation (Pax8, Nkx2-1 and FoxE1) (Gentilcore et al. 2013, Lee et al. 2017). From these results, one can presume that BPA and BPA analogs may affect thyroid function even at low doses, with a possible mechanism being through NF-kB and RAR/RXR pathways (Ghisari \& Bonefeld-Jorgensen 2005, Okada et al. 2007, Somogyi et al. 2016). Phthalate metabolites could affect 
iodine uptake through the regulation of NIS and of Slc5a5 mRNA expression (Breous et al. 2005, Wenzel et al. 2005) and by modulating hormone sulfation (Turan et al. 2005).

Several studies using animal models were controversial in demonstrating disruption of thyroid function after BPA exposure using different doses and windows of exposure. Zoeller et al. showed that there was an increase in serum concentrations of total $\mathrm{T} 4$ in pups after perinatal exposure, as early as PND 15, with no difference in TSH levels compared to levels in animals not exposed to BPA (Zoeller et al. 2005). However, another group did not detect any difference in the F1 generation of rats exposed to BPA prenatally (Kobayashi et al. 2005). Pregnant female rats exposed to BPA experienced transient hypothyroidism, while their male pups underwent transient hyperthyroidism, followed by hypothyroidism (Xu et al. 2007). Infant rats exposed during the neonatal period did not present any alterations, but the adult female animals developed a TH status similar to hypothyroidism, and evidence in a primary pituitary cell line showed that BPA alters TSH release through direct action on the pituitary (Fernandez et al. 2018). Studies with pregnant ewes, which have a gestational period more comparable to that of humans, that were exposed to BPA both subcutaneously and by dietary exposure demonstrated lower levels of THs in pregnant females and newborns, and those females showed evidence of a modified deiodination balance (Viguie et al. 2013, Guignard et al. 2017). In analyzing other windows of exposure, mice exposed to BPA during puberty have been shown to have lower free T4 levels (Jiang et al. 2016).

Animal studies of phthalates exposure have shown similar discrepancies; earlier studies suggested that phthalate metabolites could show thyromimetic effect (Price et al. 1988, Badr 1992, Gayathri et al. 2004). However, later studies were more consistent in showing a thyroid antagonistic effect, causing reductions in $\mathrm{TH}$ levels and signs of multigenerational and persistent effects (Pereira et al. 2007, Erkekoglu et al. 2012, Liu et al. 2015, Dong et al. 2017, Mahaboob Basha \& Radha 2017, Sun et al. 2018). Evidence shows disruption of the TSH/ TSHR pathway, with involvement of the hypothalamus (Dong et al. 2017, Sun et al. 2018), and of the TH synthesis machinery (downregulation of NIS, TPO, D1s and transthyretin), as well as increased TH metabolism caused by increased expression of hepatic enzymes (Liu et al. 2015). Phthalates, particularly di-n-butyl phthalate (DBP), might also exacerbate chronic lymphocytic thyroiditis by inducing oxidative stress and changes in serum TBG levels and thyroid interleukin-7 (IL-7) levels (Johns et al. 2016).
In humans, the available data are even more controversial; two prospective studies, CHAMACOS (Chevrier et al. 2013) and HOME, have evaluated the possible associations of BPA with THs during pregnancy and in neonates, and the results are somewhat similar regarding neonatal thyroid profiles, with a negative correlation between BPA exposure and TSH levels only in male newborns in the CHAMACOS study and in female newborns in the HOME study, with the strongest association found when exposure occurred later in pregnancy (Chevrier et al. 2013, Romano et al. 2015). Only the CHAMACOS study observed an inverse association between BPA exposure and total T4 levels in pregnant women (Chevrier et al. 2013).

Regarding possible interference from phthalates during pregnancy, the majority of studies have reported a negative correlation between levels of several metabolites and THs, particularly free and total T4 and free T3 levels, and a positive correlation with TSH levels, and these effects may depend on the timing of exposure during gestation (Huang et al. 2007, 2016, Johns et al. 2015, Yao et al. 2016, Gao et al. 2017). However, other studies have shown very different results, with an inverse association with TSH and a positive association with free and total T4 levels (Huang et al. 2007, 2016, Johns et al. 2015, 2016, Yao et al. 2016, Gao et al. 2017). Regarding phthalate exposure and neonatal thyroid status, some studies have shown a correlation between phthalate levels and TH levels in newborns; a Dutch prospective cohort detected changes in free T4 levels in girls but not in boys (de Cock et al. 2014), and a study in Taiwan found an association of phthalate exposure with reduced levels of THs in young children (Huang et al. 2017a,b).

No evidence of an association between phthalate exposure and changes in TH levels was detected in children exposed during the use of extracorporeal oxygenation or after using DEHP-tainted foodstuffs (illegal use of DEHP in food from Taiwan); however, in the second group, a reduction in TSH levels was detected just after exposure (Rais-Bahrami et al. 2004, Wu et al. 2013, Tsai et al. $2016 a, b)$. There is evidence in the literature of changes in TH levels, with a negative association of phthalate exposure with serum levels of THs, primarily in girls (Boas et al. 2010, Morgenstern et al. 2017). By contrast, another study showed a different thyroid profile, with sex-specific and metabolite-specific positive changes in TH levels (Weng et al. 2017).

Results from epidemiological cross-sectional studies vary for the different populations analyzed. In the National Health and Nutrition Examination Survey 
(NHANES) 2007-2008, BPA and several other chemicals such as perchlorate and phthalates were correlated with reductions in T4 levels in males, but when BPA was analyzed individually, there was no association with TH fluctuation, while phthalate metabolites such as DEHP and DBP presented negative correlations with free and total T4, total T3 and thyroglobulin levels and a positive correlation with TSH levels, suggesting that these metabolites share a similar source and that there are sex-based differences in how the thyroid responds to phthalates (Meeker \& Ferguson 2011, Mendez \& Eftim 2012, Kim et al. 2017, Przybyla et al. 2018). Similar results for phthalates were found in the Korean National Environmental Health Survey (KoNEHS) 2012-2014, but BPA presented a negative association with TSH (Park et al. 2017). However, in a similar health cross-sectional study in Thailand, the Thai National Health Examination Survey IV 2009, a negative correlation between BPA and free T4 was detected in males, without changes in TSH levels (Sriphrapradang et al. 2013), and in this same group, BPA was also associated with thyroid autoimmunity, with an increase in TPO antibody positivity (Chailurkit et al. 2016). The Taiwan Environmental Survey for Toxicants (TEST) 2013 showed negative associations between free and total T4 levels and some phthalate metabolites in adults; however, a positive association with free T4 levels was found in children (Huang et al. 2017a,b). Other studies, with different population segments, such as Chinese adults, workers with occupational BPA exposure, men from a fertility clinic, and women with polycystic ovary syndrome all showed similar thyroid profiles, with increased TH levels and/or reduced TSH levels linked to BPA exposure (Meeker et al. 2010, Wang et al. 2012, 2013, Vahedi et al. 2016). By contrast, other studies showed positive correlations between urinary BPA and TSH levels (Geens et al. 2015, Andrianou et al. 2016). There is no consensus in the literature regarding phthalate exposure in male populations, with studies showing an inverse association between MEHP and free T4 and T3 levels (Geens et al. 2015, Andrianou et al. 2016Meeker et al. 2007) and another showing no disruption of TH levels in young males exposed to MEP and MBP (Janjua et al. 2007).

Since the incidence of thyroid cancer is increasing and environmental carcinogen exposure is a probable cause (Pellegriti et al. 2013), BPA seems to be a good candidate for having a role in this process based on different studies of cancer (Shafei et al. 2018). Animal models present contradictory evidence; Takagi et al. did not find any effect of BPA in promoting thyroid carcinogenesis (Takagi et al. 2002). However, other studies, both with animal models and humans, demonstrated that BPA could influence thyroid carcinogenesis, particularly through an association with excess iodine (Zhang et al. 2017a, Zhou et al. 2017). One proposed mechanisms for this process includes interference with the action of ERs, particularly the alpha isoform (Zhang et al. 2017a,b). Additionally, a recent a study based on microarray experiments, showed that BPA exposure impairs cellular defense against DNA damage, resulting in follicular cells being more likely to die or develop a genetic impairment (Porreca et al. 2017).

\section{Pesticides}

Many toxic effects of thyroid-disrupting pesticides have been recognized at various stages of development in various adult animal models and in humans. The effects on humans have mainly focused on somatic changes, as well as changes that can be inherited by subsequent generations through epigenetic mechanisms of transgenerational inheritance (Tabb \& Blumberg 2006, Andersen et al. 2008, Schug et al. 2011).

Human epidemiological studies have shown that genetic nucleotide polymorphisms in the enzyme paraoxonase 1 (PON1) gene, which encodes a serum enzyme with antioxidant and detoxification properties (Furlong et al. 2005, Eskenazi et al. 2014), can alter the activity of the enzyme and may determine the level of sensitivity to pesticide toxicity (Furlong et al. 2010). Changes in serum lipid and lipoprotein concentrations occur frequently in thyroid dysfunction; in addition, a significant reduction in PON1 activity was observed in both hyperthyroid and hypothyroid patients (Azizi et al. 2003). This supports the idea that pesticides act as thyroid disruptors in humans, and their potential detrimental effects are more pronounced in individuals who are genetically more susceptible to thyroid dysfunction (Lacasana et al. 2010).

Some pesticides have long been banned in many countries but are still present in the environment, such as DDT, HCB and chlorpyrifos (CPF), and many of these have been examined and investigated for their thyroid-disrupting abilities (Pearce \& Braverman 2009). In vitro studies on DDT exposure showed that DDT inhibits TSH release, mainly by affecting cAMP production at the post-receptor step (Santini et al. 2003), and DDT can inhibit the activity of TSHR (Rossi et al. 2007, 2009, 2018). In addition, it has been demonstrated that, in rats, a low dose of DDT increases the concentration of T3 and reduces the level of TSH (Yaglova \& Yaglov 2014). Furthermore, the stable metabolite of DDT, p,p'-DDE, has also been investigated as a thyroid 
disruptor in a study of male Mexican floriculture workers who presented with low serum levels of THs and no significant changes in TSH levels (Blanco-Munoz et al. 2016).

In a study of prenatal HCB exposure, the effect of HCB depended on the genotype of the gene encoding the D1 (Dio1) enzyme, suggesting that D1s play a role in the disruption of THs following exposure to HBC (Llop et al. 2017). Similar studies have shown that diminished T3 levels caused by HBC exposure during pregnancy can interfere with the TH levels in early newborns and affect neurodevelopment (Takser et al. 2005, Maervoet et al. 2007, Berg et al. 2017).

$\mathrm{CPF}$ is an organochlorine pesticide commonly used in households and agriculture in the United States. CPF can cross the placental barrier and mainly acts by inhibiting acetylcholinesterase. Even at low doses, this chemical can cause endocrine disruption related to neurodevelopmental defects, resulting in decreased IQ scores and impaired memory skills in children (Crumpton et al. 2000), as well as reductions in serum T4 levels (De Angelis et al. 2009, Zhang et al. 2013).

A cross-sectional study of spray paint workers showed that TSH levels were elevated in this group of workers and that T4 levels were suppressed, while T3 levels were not altered (Zaidi et al. 2006). Furthermore, the evaluation of serum samples from greenhouse workers exposed to pesticides between spring and the fall showed reductions in free T4 and free T3 levels and an increase in TSH levels (Toft et al. 2006).

Glyphosate-based herbicides (GBHs) are among the most widely used pesticides in the world, and they cause several types of endocrine disruption (Toft et al. 2006, Bai \& Ogbourne 2016). de Souza demonstrated that glyphosate could also disrupt the HPT axis (Fig. 1) (de Souza et al. 2017). The hormonal profiles of the exposed group showed decreased TSH concentrations, with no variation in the levels of THs. In addition, hypothalamic gene expression analysis of the exposed group revealed that there was a reduction in the expression of genes encoding DI 2 (Dio2) and 3 (DIO3), and TH transporters Slco1c1 (formerly Oatp1c1) and Slc16a2 (formerly Mct8). On the other hand, in the pituitary of the exposed group, Dio2, Thr (Thra1 and Thrb1), and Slc16a2 genes were expressed at higher levels. Thus, the role of GBH exposure on HPT axis disruption should be considered in populations exposed to these herbicides (de Souza et al. 2017).

Dimethoate is an organophosphate insecticide used to kill mites and aphids and is applied to crops such as citrus, cotton, fruit, olives, potatoes, tea, tobacco and vegetables.
Dimethoate was classified as an endocrine disruptor after studies showed that the treatment of lactating rats with the insecticide resulted in reduced TH secretion in pups, as well as increased plasma T3 and T4 levels and reduced iodine uptake (Mahjoubi-Samet et al. 2005).

Fipronil is used worldwide as an insecticide. It is most commonly applied to crops such as corn, sunflowers, apples, rice and beans and is also used for household and veterinary pest control (Tingle et al. 2003). It accumulates in adipose tissue and the brain (Hainzl \& Casida 1996, Simon-Delso et al. 2015). An in vitro study using fipronil and its metabolites showed that fipronil sulfone had anti-THR alpha activity (Lu et al. 2015). It also has been associated with an increase in the incidence of thyroid tumors in rats, decreased plasma T4 concentrations and increased T4 clearance in the rat liver, but these effects have not been observed in occupationally exposed humans (Takagi et al. 2002, Blair et al. 2005, Leghait et al. 2009, Herin et al. 2011). These different results might be related to the exposure dosage of the toxicant and the metabolites present in different environments (Leghait et al. 2010).

Ioxynil (IOX) is an iodine-containing herbicide used for the control of weeds (Takahashi et al. 2010). Ioxynil has been shown to bind to the TH transporter protein TBPA, in different species (Ogilvie \& Ramsden 1988, Akiyoshi et al. 2012). It has also been shown to cause epigenetic changes in DNA, resulting in post-receptor changes (Otsuka et al. 2014).

Mancozeb is an agricultural fungicide that, at different oral doses, shows the ability to reduce iodine uptake and reduce serum T4 levels in dams and adult rats (Kackar et al. 1997, Axelstad et al. 2011). In addition, a study of the thyroid axis using adult male birds exposed to Mancozeb for 30 days showed an increase in thyroid size, an increase in plasma TSH levels and a decrease in T4 and T3 levels, mainly during the breeding phase (Pandey \& Mohanty 2015).

Other widely used pesticides as acetochlor, amitrole and cyhalothrin have been tested in zebrafish and amphibian models and have been shown to affect the development and metamorphosis (Crump et al. 2002, Helbing et al. 2006, Pan et al. 2011, Tu et al. 2016), as well as the expression of a large group of genes that could affect HPT axis and thyroid function (Li et al. 2009, Pan et al. 2011, Tu et al. 2016, Yang et al. 2016, Chang et al. 2018). However, studies in mammals and humans are necessary to further study the impact of the use of these pesticides.

Thus far, compelling evidence has been presented on pesticides as endocrine disruptors; however, more 
toxicology screening is needed to identify the toxicity levels and elucidate the mechanisms underlying the effects of these pesticides.

\section{Polybrominated diphenyl ethers}

There are over 200 brominated flame retardant (BFR) compounds that are used in many industrial applications (de Wit 2002, de Wit et al. 2006, Kabir et al. 2015). Polybrominated diphenyl ethers (PBDEs) are the most common chemicals used BFRs (Mazdai et al. 2003, Streets et al. 2006, de Wit et al. 2010, Covaci et al. 2011). As a consequence, PBDEs are present in plastics, paints, textiles, furniture and other items. In general, they are commercially available in mixtures classified as pentaBDE, octaBDE and decaBDE (Talsness 2008). The compound 2,2',4,4',5-pentaBDE (BDE-99) in one of the most prevalent congeners found in humans, and the presence of PBDEs in pregnant women, the accumulation and transfer of this compound from the mother to the infant through the placenta and breast milk has been a concern of society for more than 10 years (Gomara et al. 2007, Schuhmacher et al. 2009).

Several published studies have shown a correlation between PBDE levels and changes in thyroid function to different degrees (Turyk et al. 2008, Chevrier et al. 2010, 2011, Zhang et al. 2010, Lin et al. 2011, Zota et al. 2011). How PBDE affect thyroid function is still unclear. It has been suggested that due to the chemical nature of PBDEs, this chemical could bind directly to THRs and affect the expression of T3 target genes (Fig. 2). In an in vitro study, Ren demonstrated that lower-brominated OH-PBDEs bind the inner side of the THR-biding pocket, acting as agonists (Ren et al. 2013). Additionally, as hydroxylated metabolites of PBDE, OH-PBDEs are structurally similar to T3 and can compete to bind to THRs (Kojima et al. 2009, Schreiber et al. 2010). However, the relationship between PBDEs and thyroid function was suggested based on the cognitive alterations, as many studies showed cognitive alterations associated with impaired $\mathrm{TH}$ function (Bowers et al. 2015). Single doses of 2,2',4,4'-teraBDE (BDE-47) on PND 10 (Dingemans et al. 2007) or chronic administration of decaBDE (BDE 209) during rat gestation (Xing et al. 2009) caused reductions in levels of a key factor in learning and memory, brain-derived neurotrophic factor (BDNF), which is regulated by THs (Koibuchi et al. 1999, Gilbert \& Lasley 2013, Shulga \& Rivera 2013). Blanco and collaborators treated pregnant rats from embryonic day 6 (E6) to PND 21 and observed a delay in the spatial learning task in the water maze concomitant with decreased BDNF levels in the hippocampus (Blanco et al. 2013). Effects on cognitive function, a downregulation of BDNF and a concomitant decrease in $\mathrm{TH}$ serum levels have been reported in several papers (Kodavanti \& Derr-Yellin 2002, Darnerud et al. 2007, Bowers et al. 2015).

However, there is controversy regarding the effect of the PBDEs on serum TH levels in animal models depending on the specific chemical, administration time and dose, as well as the hormone that is being evaluated. The majority of the papers found a decrease in total serum T4 levels (Stoker et al. 2004, Kuriyama et al. 2007, van der Ven et al. 2008, Blanco et al. 2013, Kim et al. 2013, Bowers et al. 2015) and total and free T3 levels (Stoker et al. 2004, van der Ven et al. 2008, Blanco et al. 2013, Bowers et al. 2015). A few papers have shown an increase in TH level (Reverte et al. 2014) or no correlation at all (Huang et al. 2014).

The decrease of serum TH levels could be explained by impaired TH biosynthesis impairment (Fig. 2). However, very few studies have found changes in the thyroid. Rats exposed to BDE-47 showed a significant increase in the presence of cellular debris in the follicular lumen $(+71 \%)$, together with a decrease in iodide uptake (Maranghi $e t a l$. 2013, Wu et al. 2016). However, no effect on TPO activity was observed (Wu et al. 2016).

As discussed before, the effects of THs may be affected by cellular metabolization of $\mathrm{T} 4$ and $\mathrm{T} 3$, as well as interactions with THRs (Fig. 2). Several papers studied alterations in D1 activity and THR expression in different animal models, such as birds, zebrafish and others organisms (Butt et al. 2011, Butt \& Stapleton 2013, Francois \& Verreault 2018). However, few studies have addressed these points in rodent models.

In vitro, PBDEs decreased DIO1 activity in liver cells (Butt et al. 2011) and DIO2 activity in cultured human glial cells (Roberts et al. 2015). The possible mechanism for this inhibition was suggested by Marsan and Baise who showed that OH-PBDEs compete with THRs through D1s (Marsan \& Bayse 2017).

Although PBDEs consistently cause a decrease in the serum levels of THs in rodent models, in humans, many epidemiological papers present inconsistent results (Turyk et al. 2008, Chevrier et al. 2010, 2011, Han et al. 2011, Lin et al. 2011, Kim et al. 2012, 2013, 2015). The differences in the evaluations of cause and effect from these contradictory results can be explained by the highly complex correlations that are possible with over 200 different PBDEs. For example, serum T3 levels were positively correlated with BDE-99 and BDE-209 and negatively correlated with BDE-17, BDE-28, BDE-47, BDE-183 and pentaPBDEs (Huang et al. 2014). 
In a Canadian Study evaluating pregnant women, there was a negative association between PBDEs and serum total and free T3 levels (Abdelouahab et al. 2013). In contrast with these studies, Bloom and collaborators observed an increase of free T3 levels with an increase of PBDEs in older women (Bloom et al. 2014). On the other hand, Leonetti found no correlation between BRFs and THs in the placenta (Leonetti et al. 2016). However, a positive association with HO-tetraBDEs and TSH was found in thyroid cancer patients with a decrease in free T4 levels (Liu et al. 2017).

The explanation for low levels of THs could be decreases in biosynthesis and secretion by the thyroid caused by direct effects on the gland or a decrease in TSH stimulation of the thyroid (Fig. 1). However, there are once again many inconsistencies in the results. TSH was correlated with BDE-17, BDE-28, BDE-47 and BDE183 and inversely correlated with BDE-99 (Huang et al. 2014). However, in cancer patients, Liu and collaborators showed a positive correlation of $\mathrm{HO}$-tetraBDEs and TSH (Liu et al. 2017).

It is important to note that TH levels in blood are tightly regulated within an individual; hence, intraindividual variation would often be negligible compared to the inter-individual variation or the wide range of reference values. Therefore, it has been suggested by some authors that small changes in TH levels in response to exposure to environmental chemicals may not be easy to detect in small human population (Boas et al. 2012). Recently, to try to end this controversy, a meta-analysis was published, indicating that the effect of PBDEs on thyroid function depends on the PBDE exposure dose and its serum levels, suggesting a u-shaped curve (Zhao et al. 2015).

\section{Take home message}

Here, we reviewed a relevant group of thyroid disruptors to which the general population is exposed to daily. These compounds are present not just in industrialized food but also in fresh preparations. Controlling the consumption of natural bioactive compounds by a population is difficult so increase the population's awareness of their potential undesirable effects is fundamental. On the other hand, there is an enormous amount of data proving the deleterious effects of the chemicals, and as a consequence, several of them have already been banned from industrial processes or have an identified reference exposure dose. It is important to note that these reference exposures dose values are based on regulatory and often non-comprehensive tests that not always take into account how the endocrine system works, especially the thyroid gland.

THs are vital for neurological development in the early stages of life (Bernal 2017), and several studies have shown that low doses of these chemicals, closer to the usual environmental contamination dose, have effects on the endocrine system, particularly in developmentally vulnerable windows (Vandenberg et al. 2012).

Thyroid function is essential during all stages of life as it affects growth, development, metabolism and the cardiovascular and immune systems, and the continuous exposure to natural and artificial thyroid disruptors will deeply affect quality of life.

\section{Declaration of interest}

The authors declare that there is no conflict of interest that could be perceived as prejudicing the impartiality of this review.

\section{Funding}

This work was supported by grants from the Ministério da Ciência, Tecnologia e Inovação, Conselho Nacional de Desenvolvimento Científico e Tecnológico, CNPq (grant numbers: 304667/2016-1, 305427/2013-0, 422441/2016-3); Fundação Carlos Chagas Filho de Amparo a Pesquisa do Estado do Rio de Janeiro (grant numbers: CNE 2015/E26/202924/2015, CNE 2015/E26/203.190/2015) and Fundação de Amparo a Pesquisa do Estado de São Paulo (grant number: 2013/26851-7).

\section{References}

Abdelouahab N, Langlois MF, Lavoie L, Corbin F, Pasquier JC \& Takser L 2013 Maternal and cord-blood thyroid hormone levels and exposure to polybrominated diphenyl ethers and polychlorinated biphenyls during early pregnancy. American Journal of Epidemiology $\mathbf{1 7 8}$ 701-713. (https://doi.org/10.1093/aje/kwt141)

Agic A, Xu H, Altgassen C, Noack F, Wolfler MM, Diedrich K, Friedrich M, Taylor RN \& Hornung D 2007 Relative expression of 1,25-dihydroxyvitamin D3 receptor, vitamin D 1 alpha-hydroxylase, vitamin D 24-hydroxylase, and vitamin D 25-hydroxylase in endometriosis and gynecologic cancers. Reproductive Sciences $\mathbf{1 4}$ 486-497. (https://doi.org/10.1177/1933719107304565)

Akiyoshi S, Sai G \& Yamauchi K 2012 Species-dependent effects of the phenolic herbicide ioxynil with potential thyroid hormone disrupting activity: modulation of its cellular uptake and activity by interaction with serum thyroid hormone-binding proteins. Journal of Environmental Sciences 24 949-955. (https://doi.org/10.1016/S10010742(11)60819-X)

Andersen HR, Schmidt IM, Grandjean P, Jensen TK, Budtz-Jorgensen E, Kjaerstad MB, Baelum J, Nielsen JB, Skakkebaek NE \& Main KM 2008 Impaired reproductive development in sons of women occupationally exposed to pesticides during pregnancy. Environmental Health Perspectives 116 566-572. (https://doi.org/10.1289/ehp.10790)

Andrianou XD, Gangler S, Piciu A, Charisiadis P, Zira C, Aristidou K, Piciu D, Hauser R \& Makris KC 2016 Human exposures to bisphenol $\mathrm{A}$, bisphenol $\mathrm{F}$ and chlorinated bisphenol A derivatives and thyroid function. PLOS ONE 11 e0155237. (https://doi.org/10.1371/journal. pone.0155237) 
Aulerich RJ \& Ringer RK 1977 Current status of PCB toxicity to mink, and effect on their reproduction. Archives of Environmental Contamination and Toxicology 6 279-292. (https://doi.org/10.1007/ BF02097769)

Aulerich RJ, Ringer RK \& Iwamoto S 1973 Reproductive failure and mortality in mink fed on Great Lakes fish. Journal of Reproduction and Fertility: Supplement 19 365-376.

Aung MT, Johns LE, Ferguson KK, Mukherjee B, McElrath TF \& Meeker JD 2017 Thyroid hormone parameters during pregnancy in relation to urinary bisphenol A concentrations: a repeated measures study. Environment International 104 33-40. (https://doi. org/10.1016/j.envint.2017.04.001)

Axelstad M, Boberg J, Nellemann C, Kiersgaard M, Jacobsen PR, Christiansen S, Hougaard KS \& Hass U 2011 Exposure to the widely used fungicide mancozeb causes thyroid hormone disruption in rat dams but no behavioral effects in the offspring. Toxicological Sciences 120 439-446. (https://doi.org/10.1093/toxsci/kfr006)

Azizi F, Raiszadeh F, Solati M, Etemadi A, Rahmani M \& Arabi M 2003 Serum paraoxonase 1 activity is decreased in thyroid dysfunction. Journal of Endocrinological Investigation 26 703-709. (https://doi. org/10.1007/BF03347350)

Badr MZ 1992 Induction of peroxisomal enzyme activities by di-(2ethylhexyl) phthalate in thyroidectomized rats with parathyroid replants. Journal of Pharmacology and Experimental Therapeutics 263 1105-1110.

Bai SH \& Ogbourne SM 2016 Glyphosate: environmental contamination, toxicity and potential risks to human health via food contamination. Environmental Science and Pollution Research 23 18988-19001. (https://doi.org/10.1007/s11356-016-7425-3)

Bartsch W, Dasenbrock C, Ernst H, Kamino K \& Mohr U 1996 Absence of effect of caffeine on the thyroid in the Syrian golden hamster: results of a 90-day study. Food and Chemical Toxicology 34 153-159. (https://doi.org/10.1016/0278-6915(95)00095-X)

Bellanger M, Demeneix B, Grandjean P, Zoeller RT \& Trasande L 2015 Neurobehavioral deficits, diseases, and associated costs of exposure to endocrine-disrupting chemicals in the European Union. Journal of Clinical Endocrinology and Metabolism 100 1256-1266. (https://doi. org/10.1210/jc.2014-4323)

Bento-Bernardes T, Toste FP, Pazos-Moura CC \& Oliveira KJ 2017 Maternal cinnamon extract intake during lactation leads to sexspecific endocrine modifications in rat offspring. Journal of the Science of Food and Agriculture 97 3855-3863. (https://doi.org/10.1002/ jsfa.8253)

Berg V, Nost TH, Pettersen RD, Hansen S, Veyhe AS, Jorde R, Odland JO \& Sandanger TM 2017 Persistent organic pollutants and the association with maternal and infant thyroid homeostasis: a multipollutant assessment. Environmental Health Perspectives 125 127-133. (https://doi.org/10.1289/EHP152)

Bernal J 2017 Thyroid hormone regulated genes in cerebral cortex development. Journal of Endocrinology 232 R83-R97. (https://doi. org/10.1530/JOE-16-0424)

Bernal J, Guadano-Ferraz A \& Morte B 2015 Thyroid hormone transporters - functions and clinical implications. Nature Reviews Endocrinology 11 406-417. (https://doi.org/10.1038/nrendo.2015.66)

Blair A, Sandler D, Thomas K, Hoppin JA, Kamel F, Coble J, Lee WJ, Rusiecki J, Knott C, Dosemeci M, et al. 2005 Disease and injury among participants in the Agricultural Health Study. Journal of Agricultural Safety and Health 11 141-150. (https://doi. org/10.13031/2013.18180)

Blanco J, Mulero M, Heredia L, Pujol A, Domingo JL \& Sanchez DJ 2013 Perinatal exposure to BDE-99 causes learning disorders and decreases serum thyroid hormone levels and BDNF gene expression in hippocampus in rat offspring. Toxicology 308 122-128. (https://doi. org/10.1016/j.tox.2013.03.010)

Blanco-Munoz J, Lacasana M, Lopez-Flores I, Rodriguez-Barranco M, Gonzalez-Alzaga B, Bassol S, Cebrian ME, Lopez-Carrillo L \& Aguilar-
Garduno C 2016 Association between organochlorine pesticide exposure and thyroid hormones in floriculture workers. Environmental Research 150 357-363. (https://doi.org/10.1016/j. envres.2016.05.054)

Bloom MS, Jansing RL, Kannan K, Rej R \& Fitzgerald EF 2014 Thyroid hormones are associated with exposure to persistent organic pollutants in aging residents of upper Hudson River communities. International Journal of Hygiene and Environmental Health $\mathbf{2 1 7}$ 473-482. (https://doi.org/10.1016/j.ijheh.2013.09.003)

Boas M, Frederiksen H, Feldt-Rasmussen U, Skakkebaek NE, Hegedus L, Hilsted L, Juul A \& Main KM 2010 Childhood exposure to phthalates: associations with thyroid function, insulin-like growth factor I, and growth. Environmental Health Perspectives 118 1458-1464. (https://doi.org/10.1289/ehp.0901331)

Boas M, Feldt-Rasmussen U \& Main KM 2012 Thyroid effects of endocrine disrupting chemicals. Molecular and Cellular Endocrinology 355 240-248. (https://doi.org/10.1016/j.mce.2011.09.005)

Bode AM \& Dong Z 2015 Toxic phytochemicals and their potential risks for human cancer. Cancer Prevention Research 8 1-8. (https://doi. org/10.1158/1940-6207.CAPR-14-0160)

Bottner M, Christoffel J, Rimoldi G \& Wuttke W 2006 Effects of longterm treatment with resveratrol and subcutaneous and oral estradiol administration on the pituitary-thyroid-axis. Experimental and Clinical Endocrinology and Diabetes 114 82-90. (https://doi. org/10.1055/s-2006-923888)

Bowers WJ, Wall PM, Nakai JS, Yagminas A, Wade M \& Li N 2015 Behavioral and thyroid effects of in utero and lactational exposure of Sprague-Dawley rats to the polybrominated diphenyl ether mixture DE71. Neurotoxicology and Teratology 52 127-142. (https:// doi.org/10.1016/j.ntt.2015.08.002)

Breous E, Wenzel A \& Loos U 2005 The promoter of the human sodium/ iodide symporter responds to certain phthalate plasticisers. Molecular and Cellular Endocrinology 244 75-78. (https://doi.org/10.1016/j. mce.2005.06.009)

Butt CM \& Stapleton HM 2013 Inhibition of thyroid hormone sulfotransferase activity by brominated flame retardants and halogenated phenolics. Chemical Research in Toxicology 26 1692-1702. (https://doi.org/10.1021/tx400342k)

Butt CM, Wang D \& Stapleton HM 2011 Halogenated phenolic contaminants inhibit the in vitro activity of the thyroid-regulating deiodinases in human liver. Toxicological Sciences 124 339-347. (https://doi.org/10.1093/toxsci/kfr117)

Camacho S, Michlig S, de Senarclens-Bezencon C, Meylan J, Meystre J, Pezzoli M, Markram H \& le Coutre J 2015 Anti-obesity and antihyperglycemic effects of cinnamaldehyde via altered ghrelin secretion and functional impact on food intake and gastric emptying. Scientific Reports 5 7919. (https://doi.org/10.1038/ srep07919)

Chailurkit LO, Aekplakorn W \& Ongphiphadhanakul B 2016 The association of serum bisphenol A with thyroid autoimmunity. International Journal of Environmental Research and Public Health 13 1153. (https://doi.org/10.3390/ijerph13111153)

Chang J, Hao W, Xu Y, Xu P, Li W, Li J \& Wang H 2018 Stereoselective degradation and thyroid endocrine disruption of lambda-cyhalothrin in lizards (Eremias argus) following oral exposure. Environmental Pollution 232 300-309. (https://doi.org/10.1016/j. envpol.2017.09.072)

Chavarria D, Silva T, Magalhaes e Silva D, Remiao F \& Borges F 2016 Lessons from black pepper: piperine and derivatives thereof. Expert Opinion on Therapeutic Patents 26 245-264. (https://doi.org/10.1517/1 3543776.2016.1118057)

Cheserek MJ, Wu G, Li L, Li L, Karangwa E, Shi Y \& Le G 2016 Cardioprotective effects of lipoic acid, quercetin and resveratrol on oxidative stress related to thyroid hormone alterations in long-term obesity. Journal of Nutritional Biochemistry 33 36-44. (https://doi. org/10.1016/j.jnutbio.2016.02.008) 
Chevrier J, Harley KG, Bradman A, Gharbi M, Sjodin A \& Eskenazi B 2010 Polybrominated diphenyl ether (PBDE) flame retardants and thyroid hormone during pregnancy. Environmental Health Perspectives 118 1444-1449. (https://doi.org/10.1289/ehp.1001905)

Chevrier J, Harley KG, Bradman A, Sjodin A \& Eskenazi B 2011 Prenatal exposure to polybrominated diphenyl ether flame retardants and neonatal thyroid-stimulating hormone levels in the CHAMACOS study. American Journal of Epidemiology 174 1166-1174. (https://doi. org/10.1093/aje/kwr223)

Chevrier J, Gunier RB, Bradman A, Holland NT, Calafat AM, Eskenazi B \& Harley KG 2013 Maternal urinary bisphenol a during pregnancy and maternal and neonatal thyroid function in the CHAMACOS study. Environmental Health Perspectives 121 138-144. (https://doi. org/10.1289/ehp.1205092)

Chilton FH, Dutta R, Reynolds LM, Sergeant S, Mathias RA \& Seeds MC 2017 Precision nutrition and omega-3 polyunsaturated fatty acids: a case for personalized supplementation approaches for the prevention and management of human diseases. Nutrients 9 1165. (https://doi. org/10.3390/nu9111165)

Clandinin MT, Claerhout DL \& Lien EL 1998 Docosahexaenoic acid increases thyroid-stimulating hormone concentration in male and adrenal corticotrophic hormone concentration in female weanling rats. Journal of Nutrition 128 1257-1261. (https://doi.org/10.1093/ jn/128.8.1257)

Clozel M, Branchaud CL, Tannenbaum GS, Dussault JH \& Aranda JV 1983 Effect of caffeine on thyroid and pituitary function in newborn rats. Pediatric Research 17 592-595. (https://doi. org/10.1203/00006450-198307000-00015)

Covaci A, Harrad S, Abdallah MA, Ali N, Law RJ, Herzke D \& de Wit CA 2011 Novel brominated flame retardants: a review of their analysis, environmental fate and behaviour. Environment International $\mathbf{3 7}$ 532-556. (https://doi.org/10.1016/j.envint.2010.11.007)

Crump D, Werry K, Veldhoen N, Van Aggelen G \& Helbing CC 2002 Exposure to the herbicide acetochlor alters thyroid hormonedependent gene expression and metamorphosis in Xenopus Laevis. Environmental Health Perspectives 110 1199-1205. (https://doi. org/10.1289/ehp.021101199)

Crumpton TL, Seidler FJ \& Slotkin TA 2000 Developmental neurotoxicity of chlorpyrifos in vivo and in vitro: effects on nuclear transcription factors involved in cell replication and differentiation. Brain Research 857 87-98. (https://doi.org/10.1016/S00068993(99)02357-4)

Darnerud PO, Aune M, Larsson L \& Hallgren S 2007 Plasma PBDE and thyroxine levels in rats exposed to Bromkal or BDE-47. Chemosphere 67 S386-S392. (https://doi.org/10.1016/j.chemosphere.2006.05.133)

De Angelis S, Tassinari R, Maranghi F, Eusepi A, Di Virgilio A, Chiarotti F, Ricceri L, Venerosi Pesciolini A, Gilardi E, Moracci G, et al. 2009 Developmental exposure to chlorpyrifos induces alterations in thyroid and thyroid hormone levels without other toxicity signs in CD-1 mice. Toxicological Sciences 108 311-319. (https://doi.org/10.1093/toxsci/kfp017)

de Cock M, de Boer MR, Lamoree M, Legler J \& van de Bor M 2014 Prenatal exposure to endocrine disrupting chemicals in relation to thyroid hormone levels in infants - a Dutch prospective cohort study. Environmental Health 13 106. (https://doi.org/10.1186/1476069X-13-106)

de Souza JS, Kizys MM, da Conceicao RR, Glebocki G, Romano RM, Ortiga-Carvalho TM, Giannocco G, da Silva ID, Dias da Silva MR, Romano MA, et al. 2017 Perinatal exposure to glyphosate-based herbicide alters the thyrotrophic axis and causes thyroid hormone homeostasis imbalance in male rats. Toxicology 377 25-37. (https:// doi.org/10.1016/j.tox.2016.11.005)

de Souza Dos Santos MC, Goncalves CF, Vaisman M, Ferreira AC \& de Carvalho DP 2011 Impact of flavonoids on thyroid function. Food and Chemical Toxicology 49 2495-2502. (https://doi.org/10.1016/j. fct.2011.06.074) de Wit CA 2002 An overview of brominated flame retardants in the environment. Chemosphere 46 583-624. (https://doi.org/10.1016/ S0045-6535(01)00225-9)

de Wit CA, Alaee M \& Muir DC 2006 Levels and trends of brominated flame retardants in the Arctic. Chemosphere 64 209-233. (https://doi. org/10.1016/j.chemosphere.2005.12.029)

de Wit CA, Herzke D \& Vorkamp K 2010 Brominated flame retardants in the Arctic environment - trends and new candidates. Science of the Total Environment 408 2885-2918. (https://doi.org/10.1016/j. scitotenv.2009.08.037)

Diamanti-Kandarakis E, Bourguignon JP, Giudice LC, Hauser R, Prins GS, Soto AM, Zoeller RT \& Gore AC 2009 Endocrine-disrupting chemicals: an Endocrine Society scientific statement. Endocrine Reviews 30 293-342. (https://doi.org/10.1210/er.2009-0002)

Dingemans MM, Ramakers GM, Gardoni F, van Kleef RG, Bergman A, Di Luca M, van den Berg M, Westerink RH \& Vijverberg HP 2007 Neonatal exposure to brominated flame retardant BDE-47 reduces long-term potentiation and postsynaptic protein levels in mouse hippocampus. Environmental Health Perspectives 115 865-870. (https://doi.org/10.1289/ehp.9860)

Doerge DR \& Chang HC 2002 Inactivation of thyroid peroxidase by soy isoflavones, in vitro and in vivo. Journal of Chromatography B $\mathbf{7 7 7}$ 269-279. (https://doi.org/10.1016/S1570-0232(02)00214-3)

Dong X, Dong J, Zhao Y, Guo J, Wang Z, Liu M, Zhang Y \& Na X 2017 Effects of long-term in vivo exposure to di-2-ethylhexylphthalate on thyroid hormones and the TSH/TSHR signaling pathways in wistar rats. International Journal of Environmental Research and Public Health 14 44. (https://doi.org/10.3390/ijerph14010044)

Erkekoglu P, Giray BK, Kizilgun M, Hininger-Favier I, Rachidi W, Roussel AM, Favier A \& Hincal F 2012 Thyroidal effects of di-(2ethylhexyl) phthalate in rats of different selenium status. Journal of Environmental Pathology, Toxicology and Oncology 31 143-153. (https:// doi.org/10.1615/JEnvironPatholToxicolOncol.v31.i2.60)

Eskenazi B, Kogut K, Huen K, Harley KG, Bouchard M, Bradman A, Boyd-Barr D, Johnson C \& Holland N 2014 Organophosphate pesticide exposure, PON1, and neurodevelopment in school-age children from the CHAMACOS study. Environmental Research 134 149-157. (https://doi.org/10.1016/j.envres.2014.07.001)

Felker P, Bunch R \& Leung AM 2016 Concentrations of thiocyanate and goitrin in human plasma, their precursor concentrations in brassica vegetables, and associated potential risk for hypothyroidism. Nutrition Reviews 74 248-258. (https://doi.org/10.1093/nutrit/ nuv110)

Fernandez MO, Bourguignon NS, Arocena P, Rosa M, Libertun C \& LuxLantos V 2018 Neonatal exposure to bisphenol A alters the hypothalamic-pituitary-thyroid axis in female rats. Toxicology Letters 285 81-86. (https://doi.org/10.1016/j.toxlet.2017.12.029)

Francois A \& Verreault J 2018 Interaction between deca-BDE and hepatic deiodinase in a highly PBDE-exposed bird. Environmental Research 163 108-114. (https://doi.org/10.1016/j.envres.2018.01.001)

Friedrich N, Pietzner M, Cannet C, Thuesen BH, Hansen T, Wallaschofski H, Grarup N, Skaaby T, Budde K, Pedersen O, et al. 2017 Urinary metabolomics reveals glycemic and coffee associated signatures of thyroid function in two population-based cohorts. PLoS ONE 12 e0173078. (https://doi.org/10.1371/journal.pone.0173078)

Furlong CE, Cole TB, Jarvik GP, Pettan-Brewer C, Geiss GK, Richter RJ, Shih DM, Tward AD, Lusis AJ \& Costa LG 2005 Role of paraoxonase (PON1) status in pesticide sensitivity: genetic and temporal determinants. Neurotoxicology 26 651-659. (https://doi.org/10.1016/j. neuro.2004.08.002)

Furlong CE, Suzuki SM, Stevens RC, Marsillach J, Richter RJ, Jarvik GP, Checkoway H, Samii A, Costa LG, Griffith A, et al. 2010 Human PON1, a biomarker of risk of disease and exposure. Chemico-Biological Interactions 187 355-361. (https://doi.org/10.1016/j.cbi.2010.03.033)

Gaique TG, Lopes BP, Souza LL, Paula GS, Pazos-Moura CC \& Oliveira KJ 2016 Cinnamon intake reduces serum T3 level and modulates 
tissue-specific expression of thyroid hormone receptor and target genes in rats. Journal of the Science of Food and Agriculture 96 2889-2895. (https://doi.org/10.1002/jsfa.7460)

Gaitan E 1990 Goitrogens in food and water. Annual Review of Nutrition 10 21-39. (https://doi.org/10.1146/annurev.nu.10.070190.000321)

Gambini J, Ingles M, Olaso G, Lopez-Grueso R, Bonet-Costa V, GimenoMallench L, Mas-Bargues C, Abdelaziz KM, Gomez-Cabrera MC, Vina J, et al. 2015 Properties of resveratrol: in vitro and in vivo studies about metabolism, bioavailability, and biological effects in animal models and humans. Oxidative Medicine and Cellular Longevity 2015 837042. (https://doi.org/10.1155/2015/837042)

Gao H, Wu W, Xu Y, Jin Z, Bao H, Zhu P, Su P, Sheng J, Hao J \& Tao F 2017 Effects of prenatal phthalate exposure on thyroid hormone concentrations beginning at the embryonic stage. Scientific Reports 7 13106. (https://doi.org/10.1038/s41598-017-13672-x)

Gayathri NS, Dhanya CR, Indu AR \& Kurup PA 2004 Changes in some hormones by low doses of di (2-ethyl hexyl) phthalate (DEHP), a commonly used plasticizer in PVC blood storage bags and medical tubing. Indian Journal of Medical Research 119 139-144.

Geens T, Dirtu AC, Dirinck E, Malarvannan G, Van Gaal L, Jorens PG \& Covaci A 2015 Daily intake of bisphenol A and triclosan and their association with anthropometric data, thyroid hormones and weight loss in overweight and obese individuals. Environment International 76 98-105. (https://doi.org/10.1016/j. envint.2014.12.003)

Gentilcore D, Porreca I, Rizzo F, Ganbaatar E, Carchia E, Mallardo M, De Felice M \& Ambrosino C 2013 Bisphenol A interferes with thyroid specific gene expression. Toxicology 304 21-31. (https://doi. org/10.1016/j.tox.2012.12.001)

Ghisari M \& Bonefeld-Jorgensen EC 2005 Impact of environmental chemicals on the thyroid hormone function in pituitary rat GH3 cells. Molecular and Cellular Endocrinology 244 31-41. (https://doi. org/10.1016/j.mce.2005.01.013)

Gilbert ME \& Lasley SM 2013 Developmental thyroid hormone insufficiency and brain development: a role for brain-derived neurotrophic factor (BDNF)? Neuroscience 239 253-270. (https://doi. org/10.1016/j.neuroscience.2012.11.022)

Gilbertson M \& Reynolds LM 1972 Hexachlorobenzene (HCB) in the eggs of common terns in Hamilton Harbour, Ontario. Bulletin of Environmental Contamination and Toxicology 7 371-373. (https://doi. org/10.1007/BF01684463)

Giuliani C, Bucci I, Di Santo S, Rossi C, Grassadonia A, Mariotti M, Piantelli M, Monaco F \& Napolitano G 2014 Resveratrol inhibits sodium/iodide symporter gene expression and function in rat thyroid cells. PLOS ONE 9 e107936. (https://doi.org/10.1371/journal. pone.0107936)

Giuliani C, Iezzi M, Ciolli L, Hysi A, Bucci I, Di Santo S, Rossi C, Zucchelli M \& Napolitano G 2017 Resveratrol has anti-thyroid effects both in vitro and in vivo. Food and Chemical Toxicology 107 237-247. (https://doi.org/10.1016/j.fct.2017.06.044)

Gomara B, Herrero L, Ramos JJ, Mateo JR, Fernandez MA, Garcia JF \& Gonzalez MJ 2007 Distribution of polybrominated diphenyl ethers in human umbilical cord serum, paternal serum, maternal serum, placentas, and breast milk from Madrid population, Spain. Environmental Science and Technology 41 6961-6968. (https://doi. org/10.1021/es0714484)

Gore AC, Chappell VA, Fenton SE, Flaws JA, Nadal A, Prins GS, Toppari J \& Zoeller RT 2015 Executive summary to EDC-2: the Endocrine Society's second scientific statement on endocrine-disrupting chemicals. Endocrine Reviews 36 593-602. (https://doi.org/10.1210/ er.2015-1093)

Guignard D, Gayrard V, Lacroix MZ, Puel S, Picard-Hagen N \& Viguie C 2017 Evidence for bisphenol A-induced disruption of maternal thyroid homeostasis in the pregnant ewe at low level representative of human exposure. Chemosphere 182 458-467. (https://doi. org/10.1016/j.chemosphere.2017.05.028)
Hainzl D \& Casida JE 1996 Fipronil insecticide: novel photochemical desulfinylation with retention of neurotoxicity. PNAS 93 12764-12767. (https://doi.org/10.1073/pnas.93.23.12764)

Han G, Ding G, Lou X, Wang X, Han J, Shen H, Zhou Y \& Du L 2011 Correlations of PCBs, DIOXIN, and PBDE with TSH in children's blood in areas of computer E-waste recycling. Biomedical and Environmental Sciences 24 112-116. (https://doi.org/10.3967/08953988.2011.02.004)

Hansen JF, Brorson MM, Boas M, Frederiksen H, Nielsen CH, Lindstrom ES, Hofman-Bang J, Hartoft-Nielsen ML, Frisch T, Main KM, et al. 2016 Phthalates are metabolised by primary thyroid cell cultures but have limited influence on selected thyroid cell functions in vitro. PLOS ONE 11 e0151192. (https://doi.org/10.1371/ journal.pone.0151192)

Heimeier RA, Das B, Buchholz DR \& Shi YB 2009 The xenoestrogen bisphenol A inhibits postembryonic vertebrate development by antagonizing gene regulation by thyroid hormone. Endocrinology 150 2964-2973. (https://doi.org/10.1210/en.2008-1503)

Helbing CC, Ovaska K \& Ji L 2006 Evaluation of the effect of acetochlor on thyroid hormone receptor gene expression in the brain and behavior of Rana catesbeiana tadpoles. Aquatic Toxicology 80 42-51. (https://doi.org/10.1016/j.aquatox.2006.07.011)

Herin F, Boutet-Robinet E, Levant A, Dulaurent S, Manika M, GalatryBouju F, Caron P \& Soulat JM 2011 Thyroid function tests in persons with occupational exposure to fipronil. Thyroid 21 701-706. (https:// doi.org/10.1089/thy.2010.0449)

Hlebowicz J, Hlebowicz A, Lindstedt S, Bjorgell O, Hoglund P, Holst JJ, Darwiche G \& Almer LO 2009 Effects of 1 and $3 \mathrm{~g}$ cinnamon on gastric emptying, satiety, and postprandial blood glucose, insulin, glucose-dependent insulinotropic polypeptide, glucagon-like peptide 1 , and ghrelin concentrations in healthy subjects. American Journal of Clinical Nutrition 89 815-821. (https://doi.org/10.3945/ ajcn.2008.26807)

Hu X, Shi W, Zhang F, Cao F, Hu G, Hao Y, Wei S, Wang X \& Yu H 2013 In vitro assessment of thyroid hormone disrupting activities in drinking water sources along the Yangtze River. Environmental Pollution 173 210-215. (https://doi.org/10.1016/j. envpol.2012.10.022)

Huang PC, Kuo PL, Guo YL, Liao PC \& Lee CC 2007 Associations between urinary phthalate monoesters and thyroid hormones in pregnant women. Human Reproduction 22 2715-2722. (https://doi. org/10.1093/humrep/dem205)

Huang F, Wen S, Li J, Zhong Y, Zhao Y \& Wu Y 2014 The human body burden of polybrominated diphenyl ethers and their relationships with thyroid hormones in the general population in Northern China. Science of the Total Environment 466-467 609-615. (https:// doi.org/10.1016/j.scitotenv.2013.07.008)

Huang PC, Tsai CH, Liang WY, Li SS, Huang HB \& Kuo PL 2016 Early phthalates exposure in pregnant women is associated with alteration of thyroid hormones. PLOS ONE 11 e0159398. (https://doi. org/10.1371/journal.pone.0159398)

Huang HB, Chuang CJ, Su PH, Sun CW, Wang CJ, Wu MT \& Wang SL $2017 a$ Prenatal and childhood exposure to phthalate diesters and thyroid function in a 9-year follow-up birth cohort study: Taiwan Maternal and Infant Cohort Study. Epidemiology 28 (Supplement 1) S10-S18. (https://doi.org/10.1097/EDE.0000000000000722)

Huang HB, Pan WH, Chang JW, Chiang HC, Guo YL, Jaakkola JJ \& Huang PC 2017b Does exposure to phthalates influence thyroid function and growth hormone homeostasis? The Taiwan Environmental Survey for Toxicants (TEST) 2013. Environmental Research 153 63-72. (https://doi.org/10.1016/j.envres.2016.11.014)

Ibhazehiebo K \& Koibuchi N 2011 Thyroid hormone receptor-mediated transcription is suppressed by low dose phthalate. Nigerian Journal of Physiological Sciences 26 143-149.

Iwamuro S, Yamada M, Kato M \& Kikuyama S 2006 Effects of bisphenol A on thyroid hormone-dependent up-regulation of thyroid hormone 
receptor alpha and beta and down-regulation of retinoid $\mathrm{X}$ receptor gamma in Xenopus tail culture. Life Sciences 79 2165-2171. (https:// doi.org/10.1016/j.lfs.2006.07.013)

Janjua NR, Mortensen GK, Andersson AM, Kongshoj B, Skakkebaek NE \& Wulf HC 2007 Systemic uptake of diethyl phthalate, dibutyl phthalate, and butyl paraben following whole-body topical application and reproductive and thyroid hormone levels in humans. Environmental Science and Technology 41 5564-5570. (https://doi.org/10.1021/es0628755)

Jiang W, Cao L, Wang F, Ge H, Wu PC, Li XW \& Chen GH 2016 Accelerated reduction of serum thyroxine and hippocampal histone acetylation links to exacerbation of spatial memory impairment in aged CD-1 mice pubertally exposed to bisphenol-a. Age 38 405-418. (https://doi.org/10.1007/s11357-016-9947-5)

Jobling S, Beresford N, Nolan M, Rodgers-Gray T, Brighty GC, Sumpter JP \& Tyler CR 2002 Altered sexual maturation and gamete production in wild roach (Rutilus rutilus) living in rivers that receive treated sewage effluents. Biology of Reproduction 66 272-281. (https:// doi.org/10.1095/biolreprod66.2.272)

Johns LE, Ferguson KK, Soldin OP, Cantonwine DE, Rivera-Gonzalez LO Del Toro LV, Calafat AM, Ye X, Alshawabkeh AN, Cordero JF, et al. 2015 Urinary phthalate metabolites in relation to maternal serum thyroid and sex hormone levels during pregnancy: a longitudinal analysis. Reproductive Biology and Endocrinology 13 4. (https://doi. org/10.1186/1477-7827-13-4)

Johns LE, Ferguson KK, McElrath TF, Mukherjee B \& Meeker JD 2016 Associations between repeated measures of maternal urinary phthalate metabolites and thyroid hormone parameters during pregnancy. Environmental Health Perspectives 124 1808-1815.

Jump DB, Clarke SD, MacDougald O \& Thelen A 1993 Polyunsaturated fatty acids inhibit S14 gene transcription in rat liver and cultured hepatocytes. PNAS 90 8454-8458. (https://doi.org/10.1073/ pnas.90.18.8454)

Kabir ER, Rahman MS \& Rahman I 2015 A review on endocrine disruptors and their possible impacts on human health. Environmental Toxicology and Pharmacology 40 241-258. (https://doi. org/10.1016/j.etap.2015.06.009)

Kackar R, Srivastava MK \& Raizada RB 1997 Studies on rat thyroid after oral administration of mancozeb: morphological and biochemical evaluations. Journal of Applied Toxicology 17 369-375. (https://doi. org/10.1002/(SICI)1099-1263(199711/12)17:6<369::AIDJAT449>3.0.CO;2-Q)

Kim UJ, Kim MY, Hong YH, Lee DH \& Oh JE 2012 Assessment of impact of internal exposure to PBDEs on human thyroid function comparison between congenital hypothyroidism and normal paired blood. Environmental Science and Technology 46 6261-6268. (https:// doi.org/10.1021/es2038678)

Kim S, Park J, Kim HJ, Lee JJ, Choi G, Choi S, Kim S, Kim SY, Moon HB, Kim S, et al. 2013 Association between several persistent organic pollutants and thyroid hormone levels in serum among the pregnant women of Korea. Environment International 59 442-448. (https://doi.org/10.1016/j.envint.2013.07.009)

Kim S, Park J, Kim HJ, Lee JJ, Choi G, Choi S, Kim S, Kim SY, Moon HB, Kim S, et al. 2015 Association between several persistent organic pollutants and thyroid hormone levels in cord blood serum and bloodspot of the newborn infants of Korea. PLOS ONE $\mathbf{1 0}$ e0125213. (https://doi.org/10.1371/journal.pone.0125213)

Kim S, Kim S, Won S \& Choi K 2017 Considering common sources of exposure in association studies - urinary benzophenone-3 and DEHP metabolites are associated with altered thyroid hormone balance in the NHANES 2007-2008. Environment International 107 25-32. (https://doi.org/10.1016/j.envint.2017.06.013)

Kobayashi K, Miyagawa M, Wang RS, Suda M, Sekiguchi S \& Honma T 2005 Effects of in utero and lactational exposure to bisphenol A on thyroid status in F1 rat offspring. Industrial Health 43 685-690. (https://doi.org/10.2486/indhealth.43.685)
Kodavanti PR \& Derr-Yellin EC 2002 Differential effects of polybrominated diphenyl ethers and polychlorinated biphenyls on $[3 \mathrm{H}]$ arachidonic acid release in rat cerebellar granule neurons. Toxicological Sciences 68 451-457. (https://doi.org/10.1093/ toxsci/68.2.451)

Koibuchi N, Fukuda H \& Chin WW 1999 Promoter-specific regulation of the brain-derived neurotropic factor gene by thyroid hormone in the developing rat cerebellum. Endocrinology 140 3955-3961. (https:// doi.org/10.1210/endo.140.9.6997)

Kojima H, Takeuchi S, Uramaru N, Sugihara K, Yoshida T \& Kitamura S 2009 Nuclear hormone receptor activity of polybrominated diphenyl ethers and their hydroxylated and methoxylated metabolites in transactivation assays using Chinese hamster ovary cells. Environmental Health Perspectives 117 1210-1218. (https://doi. org/10.1289/ehp.0900753)

Kreutzer K \& Bassler D 2014 Caffeine for apnea of prematurity: a neonatal success story. Neonatology 105 332-336. (https://doi. org/10.1159/000360647)

Kuriyama SN, Wanner A, Fidalgo-Neto AA, Talsness CE, Koerner W \& Chahoud I 2007 Developmental exposure to low-dose PBDE-99: tissue distribution and thyroid hormone levels. Toxicology 242 80-90. (https://doi.org/10.1016/j.tox.2007.09.011)

Lacasana M, Lopez-Flores I, Rodriguez-Barranco M, Aguilar-Garduno C, Blanco-Munoz J, Perez-Mendez O, Gamboa R, Gonzalez-Alzaga B, Bassol S \& Cebrian ME 2010 Interaction between organophosphate pesticide exposure and PON1 activity on thyroid function. Toxicology and Applied Pharmacology 249 16-24. (https://doi.org/10.1016/j. taap.2010.07.024)

Lang R, Wahl A, Stark T \& Hofmann T 2011 Urinary $\mathrm{N}$-methylpyridinium and trigonelline as candidate dietary biomarkers of coffee consumption. Molecular Nutrition and Food Research 55 1613-1623. (https://doi.org/10.1002/mnfr.201000656)

Lee S, Kim C, Youn H \& Choi K 2017 Thyroid hormone disrupting potentials of bisphenol $\mathrm{A}$ and its analogues - in vitro comparison study employing rat pituitary (GH3) and thyroid follicular (FRTL-5) cells. Toxicology in Vitro 40 297-304. (https://doi.org/10.1016/j. tiv.2017.02.004)

Leghait J, Gayrard V, Picard-Hagen N, Camp M, Perdu E, Toutain PL \& Viguie C 2009 Fipronil-induced disruption of thyroid function in rats is mediated by increased total and free thyroxine clearances concomitantly to increased activity of hepatic enzymes. Toxicology 255 38-44. (https://doi.org/10.1016/j.tox.2008.09.026)

Leghait J, Gayrard V, Toutain PL, Picard-Hagen N \& Viguie C 2010 Is the mechanisms of fipronil-induced thyroid disruption specific of the rat: re-evaluation of fipronil thyroid toxicity in sheep? Toxicology Letters 194 51-57. (https://doi.org/10.1016/j.toxlet.2010.01.018)

Leonetti C, Butt CM, Hoffman K, Hammel SC, Miranda ML \& Stapleton HM 2016 Brominated flame retardants in placental tissues: associations with infant sex and thyroid hormone endpoints. Environmental Health 15 113. (https://doi.org/10.1186/s12940-0160199-8)

Leung AM, Korevaar TI, Peeters RP, Zoeller RT, Kohrle J, Duntas LH, Brent GA \& Demeneix BA 2016 Exposure to thyroid-disrupting chemicals: a transatlantic call for action. Thyroid 26 479-480. (https://doi.org/10.1089/thy.2016.0077)

Li W, Zha J, Li Z, Yang L \& Wang Z 2009 Effects of exposure to acetochlor on the expression of thyroid hormone related genes in larval and adult rare minnow (Gobiocypris rarus). Aquatic Toxicology 94 87-93. (https://doi.org/10.1016/j.aquatox.2009.06.002)

Li J, Ren S, Han S, Lei B \& Li N 2014 Identification of thyroid-receptor antagonists in water from the Guanting Reservoir, Beijing, China. Archives of Environmental Contamination and Toxicology 67 68-77. (https://doi.org/10.1007/s00244-014-0027-5)

Lin SM, Chen FA, Huang YF, Hsing LL, Chen LL, Wu LS, Liu TS, ChangChien GP, Chen KC \& Chao HR 2011 Negative associations between PBDE levels and thyroid hormones in cord blood. International 
Journal of Hygiene and Environmental Health 214 115-120. (https:// doi.org/10.1016/j.ijheh.2010.10.002)

Liu C, Zhao L, Wei L \& Li L 2015 DEHP reduces thyroid hormones via interacting with hormone synthesis-related proteins, deiodinases, transthyretin, receptors, and hepatic enzymes in rats. Environmental Science and Pollution Research 22 12711-12719. (https://doi. org/10.1007/s11356-015-4567-7)

Liu S, Zhao G, Li J, Zhao H, Wang Y, Chen J \& Zhao H 2017 Association of polybrominated diphenylethers (PBDEs) and hydroxylated metabolites (OH-PBDEs) serum levels with thyroid function in thyroid cancer patients. Environmental Research 159 1-8. (https://doi. org/10.1016/j.envres.2017.07.042)

Llop S, Murcia M, Alvarez-Pedrerol M, Grimalt JO, Santa-Marina L, Julvez J, Goni-Irigoyen F, Espada M, Ballester F, Rebagliato M, et al. 2017 Association between exposure to organochlorine compounds and maternal thyroid status: role of the iodothyronine deiodinase 1 gene. Environment International 104 83-90. (https://doi.org/10.1016/j. envint.2016.12.013)

Lopes BP, Gaique TG, Souza LL, Paula GS, Kluck GE, Atella GC, Gomes AC, Simas NK, Kuster RM, Ortiga-Carvalho TM, et al. 2015 Cinnamon extract improves the body composition and attenuates lipogenic processes in the liver and adipose tissue of rats. Food and Function 6 3257-3265. (https://doi.org/10.1039/C5FO00569H)

Lu M, Du J, Zhou P, Chen H, Lu C \& Zhang Q 2015 Endocrine disrupting potential of fipronil and its metabolite in reporter gene assays. Chemosphere 120 246-251. (https://doi.org/10.1016/j. chemosphere.2014.07.015)

Maervoet J, Vermeir G, Covaci A, Van Larebeke N, Koppen G, Schoeters G, Nelen V, Baeyens W, Schepens P \& Viaene MK 2007 Association of thyroid hormone concentrations with levels of organochlorine compounds in cord blood of neonates. Environmental Health Perspectives 115 1780-1786. (https://doi.org/10.1289/ ehp.10486)

Mahaboob Basha P \& Radha MJ 2017 Gestational di-n-butyl phthalate exposure induced developmental and teratogenic anomalies in rats: a multigenerational assessment. Environmental Science and Pollution Research 24 4537-4551. (https://doi.org/10.1007/s11356-016-8196-6)

Mahjoubi-Samet A, Hamadi F, Soussia L, Fadhel G \& Zeghal N 2005 Dimethoate effects on thyroid function in suckling rats. Annales d'Endocrinologie 66 96-104. (https://doi.org/10.1016/S00034266(05)81705-6)

Makino M, Oda N, Miura N, Imamura S, Yamamoto K, Kato T, Fujiwara K, Sawai Y, Iwase K, Nagasaka A, et al. 2001 Effect of eicosapentaenoic acid ethyl ester on hypothyroid function. Journal of Endocrinology 171 259-265. (https://doi.org/10.1677/joe.0.1710259)

Maranghi F, Tassinari R \& Mantovani A 2013 Toxicological assessment of drugs that affect the endocrine system in puberty-related disorders. Expert Opinion on Drug Metabolism and Toxicology 9 1309-1316. (https://doi.org/10.1517/17425255.2013.811488)

Marsan ES \& Bayse CA 2017 Halogen-bonding interactions of polybrominated diphenyl ethers and thyroid hormone derivatives: a potential mechanism for the inhibition of iodothyronine deiodinase. Chemistry 23 6625-6633. (https://doi.org/10.1002/chem.201700407)

Mazdai A, Dodder NG, Abernathy MP, Hites RA \& Bigsby RM 2003 Polybrominated diphenyl ethers in maternal and fetal blood samples. Environmental Health Perspectives 111 1249-1252. (https:// doi.org/10.1289/ehp.6146)

McLachlan JA, Newbold RR \& Bullock BC 1980 Long-term effects on the female mouse genital tract associated with prenatal exposure to diethylstilbestrol. Cancer Research 40 3988-3999.

Medagama AB 2015 The glycaemic outcomes of Cinnamon, a review of the experimental evidence and clinical trials. Nutrition Journal 14 108. (https://doi.org/10.1186/s12937-015-0098-9)

Meeker JD \& Ferguson KK 2011 Relationship between urinary phthalate and bisphenol A concentrations and serum thyroid measures in U.S. adults and adolescents from the National Health and Nutrition
Examination Survey (NHANES) 2007-2008. Environmental Health Perspectives 119 1396-1402. (https://doi.org/10.1289/ehp.1103582)

Meeker JD, Calafat AM \& Hauser R 2007 Di(2-ethylhexyl) phthalate metabolites may alter thyroid hormone levels in men. Environmental Health Perspectives 115 1029-1034. (https://doi.org/10.1289/ ehp.9852)

Meeker JD, Calafat AM \& Hauser R 2010 Urinary bisphenol A concentrations in relation to serum thyroid and reproductive hormone levels in men from an infertility clinic. Environmental Science and Technology 44 1458-1463. (https://doi.org/10.1021/ es9028292)

Mendez W Jr \& Eftim SE 2012 Biomarkers of perchlorate exposure are correlated with circulating thyroid hormone levels in the 2007-2008 NHANES. Environmental Research 118 137-144. (https://doi. org/10.1016/j.envres.2012.05.010)

Messina M \& Redmond G 2006 Effects of soy protein and soybean isoflavones on thyroid function in healthy adults and hypothyroid patients: a review of the relevant literature. Thyroid 16 249-258. (https://doi.org/10.1089/thy.2006.16.249)

Morgenstern R, Whyatt RM, Insel BJ, Calafat AM, Liu X, Rauh VA, Herbstman J, Bradwin G \& Factor-Litvak P 2017 Phthalates and thyroid function in preschool age children: sex specific associations. Environment International 106 11-18. (https://doi.org/10.1016/j. envint.2017.05.007)

Moriyama K, Tagami T, Akamizu T, Usui T, Saijo M, Kanamoto N, Hataya Y, Shimatsu A, Kuzuya H \& Nakao K 2002 Thyroid hormone action is disrupted by bisphenol $\mathrm{A}$ as an antagonist. Journal of Clinical Endocrinology and Metabolism 87 5185-5190. (https://doi. org/10.1210/jc.2002-020209)

Newbold RR, Bullock BC \& McLachlan JA 1985 Progressive proliferative changes in the oviduct of mice following developmental exposure to diethylstilbestrol. Teratogenesis, Carcinogenesis, and Mutagenesis 5 473-480. (https://doi.org/10.1002/tcm.1770050610)

O'Keefe JH, Bhatti SK, Patil HR, DiNicolantonio JJ, Lucan SC \& Lavie CJ 2013 Effects of habitual coffee consumption on cardiometabolic disease, cardiovascular health, and all-cause mortality. Journal of the American College of Cardiology 62 1043-1051. (https://doi. org/10.1016/j.jacc.2013.06.035)

Ogilvie LM \& Ramsden DB 1988 Ioxynil and 3,5,3'-triiodothyronine: comparison of binding to human plasma proteins. Toxicology Letters 44 281-287. (https://doi.org/10.1016/0378-4274(88)90167-1)

Okada K, Imaoka S, Hashimoto S, Hiroi T \& Funae Y 2007 Overexpression of protein disulfide isomerase reduces the release of growth hormone induced by bisphenol A and/or T3. Molecular and Cellular Endocrinology 278 44-51. (https://doi.org/10.1016/j. mce.2007.08.005)

Ortiga-Carvalho TM, Sidhaye AR \& Wondisford FE 2014 Thyroid hormone receptors and resistance to thyroid hormone disorders. Nature Reviews Endocrinology 10 582-591. (https://doi.org/10.1038/ nrendo.2014.143)

Ortiga-Carvalho TM, Chiamolera MI, Pazos-Moura CC \& Wondisford FE 2016 Hypothalamus-pituitary-thyroid axis. Comprehensive Physiology 6 1387-1428. (https://doi.org/10.1002/cphy.c150027)

Otsuka S, Ishihara A \& Yamauchi K 2014 Ioxynil and tetrabromobisphenol A suppress thyroid-hormone-induced activation of transcriptional elongation mediated by histone modifications and RNA polymerase II phosphorylation. Toxicological Sciences 138 290-299. (https://doi.org/10.1093/toxsci/kfu012)

Pan H, Sun Y \& Zhang L 2011 The effects of amitrole on thyroglobulin and iodide uptake in FRTL-5 cells. Toxicology and Industrial Health 27 187-192. (https://doi.org/10.1177/0748233710386405)

Panda S \& Kar A 2003a Piperine lowers the serum concentrations of thyroid hormones, glucose and hepatic 5'D activity in adult male mice. Hormone and Metabolic Research 35 523-526.

Panda S \& Kar A $2003 b$ Water and ethanol extracts of piper nigrum in regulating thyroid function and lipid peroxidation in mice. 
Pharmaceutical Biology 41 479-482. (https://doi.org/10.1080/13880 200308951338)

Pandey SP \& Mohanty B 2015 The neonicotinoid pesticide imidacloprid and the dithiocarbamate fungicide mancozeb disrupt the pituitarythyroid axis of a wildlife bird. Chemosphere 122 227-234. (https:// doi.org/10.1016/j.chemosphere.2014.11.061)

Park C, Choi W, Hwang M, Lee Y, Kim S, Yu S, Lee I, Paek D \& Choi K 2017 Associations between urinary phthalate metabolites and bisphenol A levels, and serum thyroid hormones among the Korean adult population - Korean National Environmental Health Survey (KoNEHS) 2012-2014. Science of the Total Environment 584-585 950-957. (https://doi.org/10.1016/j.scitotenv.2017.01.144)

Patisaul HB \& Jefferson W 2010 The pros and cons of phytoestrogens. Frontiers in Neuroendocrinology 31 400-419. (https://doi.org/10.1016/j. yfrne.2010.03.003)

Pearce EN \& Braverman LE 2009 Environmental pollutants and the thyroid. Best Practice and Research: Clinical Endocrinology and Metabolism 23 801-813. (https://doi.org/10.1016/j.beem.2009.06.003)

Pellegriti G, Frasca F, Regalbuto C, Squatrito S \& Vigneri R 2013 Worldwide increasing incidence of thyroid cancer: update on epidemiology and risk factors. Journal of Cancer Epidemiology 2013 965212. (https://doi.org/10.1155/2013/965212)

Pereira C, Mapuskar K \& Vaman Rao C 2007 A two-generation chronic mixture toxicity study of Clophen A60 and diethyl phthalate on histology of adrenal cortex and thyroid of rats. Acta Histochemica 109 29-36. (https://doi.org/10.1016/j.acthis.2006.09.008)

Porreca I, Ulloa-Severino L, Almeida P, Cuomo D, Nardone A, Falco G, Mallardo M \& Ambrosino C 2017 Molecular targets of developmental exposure to bisphenol A in diabesity: a focus on endoderm-derived organs. Obesity Reviews 18 99-108. (https://doi. org/10.1111/obr.12471)

Price SC, Chescoe D, Grasso P, Wright M \& Hinton RH 1988 Alterations in the thyroids of rats treated for long periods with di-(2-ethylhexyl) phthalate or with hypolipidaemic agents. Toxicology Letters 40 37-46. (https://doi.org/10.1016/0378-4274(88)90181-6)

Przybyla J, Geldhof GJ, Smit E \& Kile ML 2018 A cross sectional study of urinary phthalates, phenols and perchlorate on thyroid hormones in US adults using structural equation models (NHANES 2007-2008). Environmental Research 163 26-35. (https://doi.org/10.1016/j. envres.2018.01.039)

Rafehi H, Ververis K \& Karagiannis TC 2012 Controversies surrounding the clinical potential of cinnamon for the management of diabetes. Diabetes, Obesity and Metabolism 14 493-499. (https://doi. org/10.1111/j.1463-1326.2011.01538.x)

Rais-Bahrami K, Nunez S, Revenis ME, Luban NL \& Short BL 2004 Follow-up study of adolescents exposed to di(2-ethylhexyl) phthalate (DEHP) as neonates on extracorporeal membrane oxygenation (ECMO) support. Environmental Health Perspectives 112 1339-1340. (https://doi.org/10.1289/ehp.6901)

Ren XM, Guo LH, Gao Y, Zhang BT \& Wan B 2013 Hydroxylated polybrominated diphenyl ethers exhibit different activities on thyroid hormone receptors depending on their degree of bromination. Toxicology and Applied Pharmacology 268 256-263. (https://doi.org/10.1016/j.taap.2013.01.026)

Reverte I, Pujol A, Domingo JL \& Colomina MT 2014 Thyroid hormones and fear learning but not anxiety are affected in adult apoE transgenic mice exposed postnatally to decabromodiphenyl ether (BDE-209). Physiology and Behavior 133 81-91. (https://doi. org/10.1016/j.physbeh.2014.05.013)

Roberts SC, Bianco AC \& Stapleton HM 2015 Disruption of type 2 iodothyronine deiodinase activity in cultured human glial cells by polybrominated diphenyl ethers. Chemical Research in Toxicology $\mathbf{2 8}$ 1265-1274. (https://doi.org/10.1021/acs.chemrestox.5b00072)

Romano ME, Webster GM, Vuong AM, Thomas Zoeller R, Chen A, Hoofnagle AN, Calafat AM, Karagas MR, Yolton K, Lanphear BP, et al. 2015 Gestational urinary bisphenol A and maternal and newborn thyroid hormone concentrations: the HOME Study. Environmental Research 138 453-460. (https://doi.org/10.1016/j.envres.2015.03.003)

Rossi M, Dimida A, Dell'anno MT, Trincavelli ML, Agretti P, Giorgi F, Corsini GU, Pinchera A, Vitti P, Tonacchera M, et al. 2007 The thyroid disruptor 1,1,1-trichloro-2,2-bis(p-chlorophenyl)-ethane appears to be an uncompetitive inverse agonist for the thyrotropin receptor. Journal of Pharmacology and Experimental Therapeutics 320 465-474. (https://doi.org/10.1124/jpet.106.113613)

Rossi M, Dimida A, Ferrarini E, Silvano E, De Marco G, Agretti P, Aloisi G, Simoncini T, Di Bari L, Tonacchera M, et al. 2009 Presence of a putative steroidal allosteric site on glycoprotein hormone receptors. European Journal of Pharmacology 623 155-159. (https:// doi.org/10.1016/j.ejphar.2009.09.029)

Rossi M, Taddei AR, Fasciani I, Maggio R \& Giorgi F 2018 The cell biology of the thyroid-disrupting mechanism of dichlorodiphenyltrichloroethane (DDT). Journal of Endocrinological Investigation 41 67-73. (https://doi.org/10.1007/s40618-017-0716-9)

Santini F, Vitti P, Ceccarini G, Mammoli C, Rosellini V, Pelosini C, Marsili A, Tonacchera M, Agretti P, Santoni T, et al. 2003 In vitro assay of thyroid disruptors affecting TSH-stimulated adenylate cyclase activity. Journal of Endocrinological Investigation 26 950-955. (https://doi.org/10.1007/BF03348190)

Sauve S \& Desrosiers M 2014 A review of what is an emerging contaminant. Chemistry Central Journal 8 15. (https://doi. org/10.1186/1752-153X-8-15)

Schreiber T, Gassmann K, Gotz C, Hubenthal U, Moors M, Krause G, Merk HF, Nguyen NH, Scanlan TS, Abel J, et al. 2010 Polybrominated diphenyl ethers induce developmental neurotoxicity in a human in vitro model: evidence for endocrine disruption. Environmental Health Perspectives 118 572-578. (https://doi.org/10.1289/ehp.0901435)

Schug TT, Janesick A, Blumberg B \& Heindel JJ 2011 Endocrine disrupting chemicals and disease susceptibility. Journal of Steroid Biochemistry and Molecular Biology 127 204-215. (https://doi. org/10.1016/j.jsbmb.2011.08.007)

Schug TT, Johnson AF, Birnbaum LS, Colborn T, Guillette LJ Jr, Crews DP, Collins T, Soto AM, Vom Saal FS, McLachlan JA, et al. 2016 Minireview: endocrine disruptors: past lessons and future directions. Molecular Endocrinology 30 833-847. (https://doi. org/10.1210/me.2016-1096)

Schuhmacher M, Kiviranta H, Ruokojarvi P, Nadal M \& Domingo JL 2009 Concentrations of PCDD/Fs, PCBs and PBDEs in breast milk of women from Catalonia, Spain: a follow-up study. Environment International 35 607-613. (https://doi.org/10.1016/j. envint.2008.12.003)

Sebai H, Hovsepian S, Ristorcelli E, Aouani E, Lombardo D \& Fayet G 2010 Resveratrol increases iodide trapping in the rat thyroid cell line FRTL-5. Thyroid 20 195-203. (https://doi.org/10.1089/thy.2009.0171)

Semenza JC, Tolbert PE, Rubin CH, Guillette LJ Jr \& Jackson RJ 1997 Reproductive toxins and alligator abnormalities at Lake Apopka, Florida. Environmental Health Perspectives 105 1030-1032. (https:// doi.org/10.1289/ehp.971051030)

Shafei A, Ramzy MM, Hegazy AI, Husseny AK, El-Hadary UG, Taha MM \& Mosa AA 2018 The molecular mechanisms of action of the endocrine disrupting chemical bisphenol $\mathrm{A}$ in the development of cancer. Gene 647 235-243. (https://doi.org/10.1016/j. gene.2018.01.016)

Sheng ZG, Tang Y, Liu YX, Yuan Y, Zhao BQ, Chao XJ \& Zhu BZ 2012 Low concentrations of bisphenol a suppress thyroid hormone receptor transcription through a nongenomic mechanism. Toxicology and Applied Pharmacology 259 133-142. (https://doi.org/10.1016/j. taap.2011.12.018)

Shi W, Wang X, Hu G, Hao Y, Zhang X, Liu H, Wei S, Wang X \& Yu H 2011 Bioanalytical and instrumental analysis of thyroid hormone disrupting compounds in water sources along the Yangtze River. Environmental Pollution 159 441-448. (https://doi.org/10.1016/j. envpol.2010.10.023) 
Shulga A \& Rivera C 2013 Interplay between thyroxin, BDNF and GABA in injured neurons. Neuroscience 239 241-252. (https://doi. org/10.1016/j.neuroscience.2012.12.007)

Simon-Delso N, Amaral-Rogers V, Belzunces LP, Bonmatin JM, Chagnon M, Downs C, Furlan L, Gibbons DW, Giorio C, Girolami V, et al. 2015 Systemic insecticides (neonicotinoids and fipronil): trends, uses, mode of action and metabolites. Environmental Science and Pollution Research 22 5-34. (https://doi.org/10.1007/s11356-0143470-y)

Somogyi V, Horvath TL, Toth I, Bartha T, Frenyo LV, Kiss DS, Jocsak G, Kerti A, Naftolin F \& Zsarnovszky A 2016 Bisphenol A influences oestrogen- and thyroid hormone-regulated thyroid hormone receptor expression in rat cerebellar cell culture. Acta Veterinaria Hungarica 64 497-513. (https://doi.org/10.1556/004.2016.046)

Souza LL, Nunes MO, Paula GS, Cordeiro A, Penha-Pinto V, Neto JF, Oliveira KJ, do Carmo M \& Pazos-Moura CC 2010 Effects of dietary fish oil on thyroid hormone signaling in the liver. Journal of Nutritional Biochemistry 21 935-940. (https://doi.org/10.1016/j. jnutbio.2009.07.008)

Souza LL, Cordeiro A, Oliveira LS, de Paula GS, Faustino LC, OrtigaCarvalho TM, Oliveira KJ \& Pazos-Moura CC 2011 Thyroid hormone contributes to the hypolipidemic effect of polyunsaturated fatty acids from fish oil: in vivo evidence for cross talking mechanisms. Journal of Endocrinology 211 65-72. (https://doi.org/10.1530/JOE-11-0142)

Spindel ER, Wurtman RJ, McCall A, Carr DB, Conlay L, Griffith L \& Arnold MA 1984 Neuroendocrine effects of caffeine in normal subjects. Clinical Pharmacology and Therapeutics 36 402-407. (https:// doi.org/10.1038/clpt.1984.195)

Sriphrapradang C, Chailurkit LO, Aekplakorn W \&

Ongphiphadhanakul B 2013 Association between bisphenol A and abnormal free thyroxine level in men. Endocrine 44 441-447. (https://doi.org/10.1007/s12020-013-9889-y)

Stoker TE, Laws SC, Crofton KM, Hedge JM, Ferrell JM \& Cooper RL 2004 Assessment of DE-71, a commercial polybrominated diphenyl ether (PBDE) mixture, in the EDSP male and female pubertal protocols. Toxicological Sciences 78 144-155. (https://doi.org/10.1093/ toxsci/kfh029)

Streets SS, Henderson SA, Stoner AD, Carlson DL, Simcik MF \& Swackhamer DL 2006 Partitioning and bioaccumulation of PBDEs and PCBs in Lake Michigan. Environmental Science and Technology 40 7263-7269. (https://doi.org/10.1021/es061337p)

Sugiyama S, Shimada N, Miyoshi H \& Yamauchi K 2005 Detection of thyroid system-disrupting chemicals using in vitro and in vivo screening assays in Xenopus laevis. Toxicological Sciences 88 367-374. (https://doi.org/10.1093/toxsci/kfi330)

Sun D, Zhou L, Wang S, Liu T, Zhu J, Jia Y, Xu J, Chen H, Wang Q, $\mathrm{Xu}$ F, et al. 2018 Effect of Di-(2-ethylhexyl) phthalate on the hypothalamus-pituitary-thyroid axis in adolescent rat. Endocrine Journal 65 261-268. (https://doi.org/10.1507/endocrj.EJ17-0272)

Tabb MM \& Blumberg B 2006 New modes of action for endocrinedisrupting chemicals. Molecular Endocrinology 20 475-482. (https:// doi.org/10.1210/me.2004-0513)

Takagi H, Mitsumori K, Onodera H, Nasu M, Tamura T, Yasuhara K, Takegawa K \& Hirose M 2002 Improvement of a two-stage carcinogenesis model to detect modifying effects of endocrine disrupting chemicals on thyroid carcinogenesis in rats. Cancer Letters 178 1-9. (https://doi.org/10.1016/S0304-3835(01)00804-7)

Takahashi R, Hasegawa K, Takano A \& Noguchi T 2010 Structures and binding sites of phenolic herbicides in the $\mathrm{Q}(\mathrm{B})$ pocket of photosystem II. Biochemistry 49 5445-5454. (https://doi.org/10.1021/ bi100639q)

Takser L, Mergler D, Baldwin M, de Grosbois S, Smargiassi A \& Lafond J 2005 Thyroid hormones in pregnancy in relation to environmental exposure to organochlorine compounds and mercury. Environmental Health Perspectives 113 1039-1045. (https://doi.org/10.1289/ehp.7685)
Talsness CE 2008 Overview of toxicological aspects of polybrominated diphenyl ethers: a flame-retardant additive in several consumer products. Environmental Research 108 158-167. (https://doi. org/10.1016/j.envres.2008.08.008)

Talsness CE, Andrade AJ, Kuriyama SN, Taylor JA \& vom Saal FS 2009 Components of plastic: experimental studies in animals and relevance for human health. Philosophical Transactions of the Royal Society B: Biological Sciences 364 2079-2096. (https://doi.org/10.1098/ rstb.2008.0281)

Tingle CC, Rother JA, Dewhurst CF, Lauer S \& King WJ 2003 Fipronil: environmental fate, ecotoxicology, and human health concerns. Reviews of Environmental Contamination and Toxicology 176 1-66.

Toft G, Flyvbjerg A \& Bonde JP 2006 Thyroid function in Danish greenhouse workers. Environmental Health 5 32. (https://doi. org/10.1186/1476-069X-5-32)

Tome-Carneiro J, Gonzalvez M, Larrosa M, Garcia-Almagro FJ, AvilesPlaza F, Parra S, Yanez-Gascon MJ, Ruiz-Ros JA, Garcia-Conesa MT, Tomas-Barberan FA, et al. 2012 Consumption of a grape extract supplement containing resveratrol decreases oxidized LDL and ApoB in patients undergoing primary prevention of cardiovascular disease: a triple-blind, 6-month follow-up, placebo-controlled, randomized trial. Molecular Nutrition and Food Research 56 810-821. (https://doi. org/10.1002/mnfr.201100673)

Tome-Carneiro J, Larrosa M, Gonzalez-Sarrias A, Tomas-Barberan FA, Garcia-Conesa MT \& Espin JC 2013 Resveratrol and clinical trials: the crossroad from in vitro studies to human evidence. Current Pharmaceutical Design 19 6064-6093. (https://doi.org/10.2174/13816 128113199990407)

Tsai HJ, Wu CF, Tsai YC, Huang PC, Chen ML, Wang SL, Chen BH, Chen CC, Wu WC, Hsu PS, et al. 2016a Intake of phthalate-tainted foods and serum thyroid hormones in Taiwanese children and adolescents. Scientific Reports 6 30589. (https://doi.org/10.1038/ srep30589)

Tsai YA, Lin CL, Hou JW, Huang PC, Lee MC, Chen BH, Wu MT, Chen CC, Wang SL, Lee CC, et al. 2016 b Effects of high di(2ethylhexyl) phthalate (DEHP) exposure due to tainted food intake on pre-pubertal growth characteristics in a Taiwanese population. Environmental Research 149 197-205. (https://doi.org/10.1016/j. envres.2016.05.005)

Tu W, Xu C, Lu B, Lin C, Wu Y \& Liu W 2016 Acute exposure to synthetic pyrethroids causes bioconcentration and disruption of the hypothalamus-pituitary-thyroid axis in zebrafish embryos. Science of the Total Environment 542 876-885. (https://doi.org/10.1016/j. scitotenv.2015.10.131)

Turan N, Waring RH \& Ramsden DB 2005 The effect of plasticisers on 'sulphate supply' enzymes. Molecular and Cellular Endocrinology 244 15-19. (https://doi.org/10.1016/j.mce.2005.01.016)

Turyk ME, Persky VW, Imm P, Knobeloch L, Chatterton R \& Anderson HA 2008 Hormone disruption by PBDEs in adult male sport fish consumers. Environmental Health Perspectives 116 1635-1641. (https://doi.org/10.1289/ehp.11707)

Vahedi M, Saeedi A, Poorbaghi SL, Sepehrimanesh M \& Fattahi M 2016 Metabolic and endocrine effects of bisphenol A exposure in market seller women with polycystic ovary syndrome. Environmental Science and Pollution Research 23 23546-23550. (https://doi.org/10.1007/ s11356-016-7573-5)

van der Ven LT, van de Kuil T, Verhoef A, Leonards PE, Slob W, Canton RF, Germer S, Hamers T, Visser TJ, Litens S, et al. 2008 A 28-day oral dose toxicity study enhanced to detect endocrine effects of a purified technical pentabromodiphenyl ether (pentaBDE) mixture in Wistar rats. Toxicology 245 109-122. (https://doi. org/10.1016/j.tox.2007.12.016)

Vandenberg LN, Colborn T, Hayes TB, Heindel JJ, Jacobs DR Jr, Lee DH, Shioda T, Soto AM, vom Saal FS, Welshons WV, et al. 2012 Hormones and endocrine-disrupting chemicals: low-dose effects and 
nonmonotonic dose responses. Endocrine Reviews 33 378-455. (https://doi.org/10.1210/er.2011-1050)

Viguie C, Collet SH, Gayrard V, Picard-Hagen N, Puel S, Roques BB, Toutain PL \& Lacroix MZ 2013 Maternal and fetal exposure to bisphenol a is associated with alterations of thyroid function in pregnant ewes and their newborn lambs. Endocrinology 154 521-528. (https://doi.org/10.1210/en.2012-1401)

Wang F, Hua J, Chen M, Xia Y, Zhang Q, Zhao R, Zhou W, Zhang Z \& Wang B 2012 High urinary bisphenol A concentrations in workers and possible laboratory abnormalities. Occupational and Environmental Medicine 69 679-684. (https://doi.org/10.1136/oemed2011-100529)

Wang T, Lu J, Xu M, Xu Y, Li M, Liu Y, Tian X, Chen Y, Dai M, Wang W, et al. 2013 Urinary bisphenol a concentration and thyroid function in Chinese adults. Epidemiology 24 295-302. (https://doi. org/10.1097/EDE.0b013e318280e02f)

Weng TI, Chen MH, Lien GW, Chen PS, Lin JC, Fang CC \& Chen PC 2017 Effects of gender on the association of urinary phthalate metabolites with thyroid hormones in children: a prospective cohort study in Taiwan. International Journal of Environmental Research and Public Health 14 123. (https://doi.org/10.3390/ijerph14020123)

Wenzel A, Franz C, Breous E \& Loos U 2005 Modulation of iodide uptake by dialkyl phthalate plasticisers in FRTL-5 rat thyroid follicular cells. Molecular and Cellular Endocrinology 244 63-71. (https://doi.org/10.1016/j.mce.2005.02.008)

Willemin ME \& Lumen A 2017 Thiocyanate: a review and evaluation of the kinetics and the modes of action for thyroid hormone perturbations. Critical Reviews in Toxicology 47 537-563. (https://doi. org/10.1080/10408444.2017.1281590)

Williams FL, Ogston SA, van Toor H, Visser TJ \& Hume R 2005 Serum thyroid hormones in preterm infants: associations with postnatal illnesses and drug usage. Journal of Clinical Endocrinology and Metabolism 90 5954-5963. (https://doi.org/10.1210/jc.2005-1049)

Wu MT, Wu CF, Chen BH, Chen EK, Chen YL, Shiea J, Lee WT, Chao MC \& Wu JR 2013 Intake of phthalate-tainted foods alters thyroid functions in Taiwanese children. PLOS ONE 8 e55005. (https://doi.org/10.1371/journal.pone.0055005)

Wu Y, Beland FA \& Fang JL 2016 Effect of triclosan, triclocarban, 2,2',4,4'-tetrabromodiphenyl ether, and bisphenol A on the iodide uptake, thyroid peroxidase activity, and expression of genes involved in thyroid hormone synthesis. Toxicology in Vitro 32 310-319. (https://doi.org/10.1016/j.tiv.2016.01.014)

Xiao CW 2008 Health effects of soy protein and isoflavones in humans. Journal of Nutrition 138 1244S-1249S. (https://doi.org/10.1093/ jn/138.6.1244S)

Xing T, Chen L, Tao Y, Wang M, Chen J \& Ruan DY 2009 Effects of decabrominated diphenyl ether (PBDE 209) exposure at different developmental periods on synaptic plasticity in the dentate gyrus of adult rats in vivo. Toxicological Sciences 110 401-410. (https://doi. org/10.1093/toxsci/kfp114)

Xu X, Liu Y, Sadamatsu M, Tsutsumi S, Akaike M, Ushijima H \& Kato N 2007 Perinatal bisphenol A affects the behavior and SRC-1 expression of male pups but does not influence on the thyroid hormone receptors and its responsive gene. Neuroscience Research 58 149-155. (https://doi.org/10.1016/j.neures.2007.02.011)

Yaglova NV \& Yaglov VV 2014 Changes in thyroid status of rats after prolonged exposure to low dose dichlorodiphenyltrichloroethane.
Bulletin of Experimental Biology and Medicine 156 760-762. (https:// doi.org/10.1007/s10517-014-2443-y)

Yang M, Hu J, Li S, Ma Y, Gui W \& Zhu G 2016 Thyroid endocrine disruption of acetochlor on zebrafish (Danio rerio) larvae. Journal of Applied Toxicology 36 844-852. (https://doi.org/10.1002/jat.3230)

Yao HY, Han Y, Gao H, Huang K, Ge X, Xu YY, Xu YQ, Jin ZX, Sheng J, Yan SQ, et al. 2016 Maternal phthalate exposure during the first trimester and serum thyroid hormones in pregnant women and their newborns. Chemosphere 157 42-48. (https://doi.org/10.1016/j. chemosphere.2016.05.023)

Zaidi S, Tiwari R, Gandhi S, Patel K, Kumar S \& Saiyed H 2006 Neurobehavioral effects and hormones profile among spray painters. Industrial Health 44 93-97. (https://doi.org/10.2486/ indhealth.44.93)

Zhang J, Jiang Y, Zhou J, Wu B, Liang Y, Peng Z, Fang D, Liu B, Huang H, He C, et al. 2010 Elevated body burdens of PBDEs, dioxins, and PCBs on thyroid hormone homeostasis at an electronic waste recycling site in China. Environmental Science and Technology 44 3956-3962. (https://doi.org/10.1021/es902883a)

Zhang J, Hisada A, Yoshinaga J, Shiraishi H, Shimodaira K, Okai T, Noda Y, Shirakawa M \& Kato N 2013 Exposure to pyrethroids insecticides and serum levels of thyroid-related measures in pregnant women. Environmental Research 127 16-21. (https://doi. org/10.1016/j.envres.2013.10.001)

Zhang J, Zhang X, Li Y, Zhou Z, Wu C, Liu Z, Hao L, Fan S, Jiang F, Xie Y, et al. 2017a Low dose of Bisphenol A enhance the susceptibility of thyroid carcinoma stimulated by DHPN and iodine excess in F344 rats. Oncotarget 8 69874-69887. (https://doi. org/10.18632/oncotarget.19434)

Zhang Y, Wei F, Zhang J, Hao L, Jiang J, Dang L, Mei D, Fan S, Yu Y \& Jiang L 2017b Bisphenol A and estrogen induce proliferation of human thyroid tumor cells via an estrogen-receptor-dependent pathway. Archives of Biochemistry and Biophysics 633 29-39. (https:// doi.org/10.1016/j.abb.2017.09.002)

Zhao X, Wang H, Li J, Shan Z, Teng W \& Teng X 2015 The correlation between polybrominated diphenyl ethers (PBDEs) and thyroid hormones in the general population: a meta-analysis. PLOS ONE 10 e0126989. (https://doi.org/10.1371/journal.pone.0126989)

Zhou Z, Zhang J, Jiang F, Xie Y, Zhang X \& Jiang L 2017 Higher urinary bisphenol A concentration and excessive iodine intake are associated with nodular goiter and papillary thyroid carcinoma. Bioscience Reports 37 BSR20170678. (https://doi.org/10.1042/BSR20170678)

Zoeller RT, Bansal R \& Parris C 2005 Bisphenol-A, an environmental contaminant that acts as a thyroid hormone receptor antagonist in vitro, increases serum thyroxine, and alters RC3/neurogranin expression in the developing rat brain. Endocrinology 146 607-612. (https://doi.org/10.1210/en.2004-1018)

Zoeller RT, Brown TR, Doan LL, Gore AC, Skakkebaek NE, Soto AM, Woodruff TJ \& Vom Saal FS 2012 Endocrine-disrupting chemicals and public health protection: a statement of principles from The Endocrine Society. Endocrinology 153 4097-4110. (https://doi. org/10.1210/en.2012-1422)

Zota AR, Park JS, Wang Y, Petreas M, Zoeller RT \& Woodruff TJ 2011 Polybrominated diphenyl ethers, hydroxylated polybrominated diphenyl ethers, and measures of thyroid function in second trimester pregnant women in California. Environmental Science and Technology 45 7896-7905. (https://doi.org/10.1021/es200422b)

Received in final form 28 March 2018

Accepted 12 July 2018

Accepted Preprint published online 12 July 2018 (c) 2019 Society for Endocrinology Published by Bioscientifica Ltd. Printed in Great Britain 